DIVISION OF THE HUMANITIES AND SOCIAL SCIENCES

\title{
CALLFORNIA INSTITUTE OF TECHNOLOGY
}

PASADENA, CALIFORNIA 91125

THE ENFORCEABILITY OF SECURITY INTERESTS IN CONSUMER GOODS

Alan Schwartz

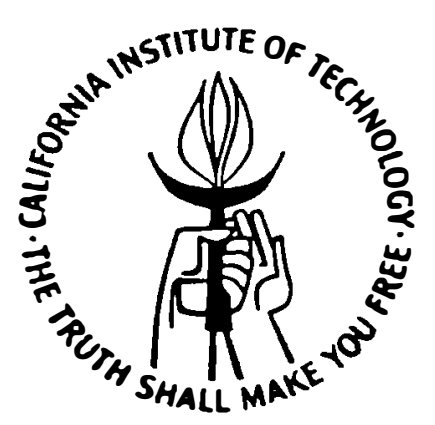

SOCIAL SCIENCE WORKING PAPER 423 
Security interests in consumer goods have been extensively regulated, this regulation taking the principal forms either of prohibiting creditors from taking such interests at all or of deliberately reducing their attractiveness as risk reduction devices. The unique feature of this consumer protection regulation is that it is not justified by the usual unconscionability reasons, such as the existence of imperfect information, but rather by the view that security disadvantages consumers even though the contracts that create it may not be unconscionable. In particular, the institutional structure is considered to create incentives for institutional structure is considered to create incentives for collateral could yield, with the result that consumers remain liable for excessive debts even after foreclosure. Also, creditors are said to threaten repossession unfairly to coerce payment; repossession allegedly destroys consumer surplus; and it supposedly violates debtors' rights. This paper argues that supposedy violates debtors' these justifications for the regulation of security interests in consumer goods are untenable or unpersuasive. Contracts to give security actually pose problems similar in kind to those posed by any other consumer contract, and should be regulated, if at all, under the same rationales. 
THE ENFORCEAPILITY OF SECURITY INTERESTS IN CONSUMER GOODS

Alan Schwartz*

Consumers who grant security interests to creditors pay lower interest rates in return, but this seemingly innocuous arrangement has recently been regulated extensiveiy. For example, the Uniform Consumer Credit Code authorizes courts to refuse to enforce certain security interests if enforcement would impose "undue hardship" on the consumer. ${ }^{1}$ Several states al so prohibit creditors who foreclose from later suing for deficiency judgments, ${ }^{2}$ in which they attempt to recover the difference between the unpaid debt and the amount realized on foreclosure. This prohibition reduces the attractiveness of security as a risk reduction device. In addition, proposals have been made to prevent creditors from taking security interests in consumer goods collateral except for purchase money security interests. ${ }^{3}$

Contracts made between competent and informed persons in competitive markets, it is assumed here, are presumptively enforceable. This is because such contracts marimize the utility of the parties to them, and commonly social utility as we11.4 Also, most nonutilitarian moral schemes accord free and autonomous persons the right to make enforceable contracts. ${ }^{5}$ If the general enforceability of contracts is assumed, two types of reasons may justify regulating contracts to give security. First, are reasons following from the failure of the presuppositions on which the "enforceability

assumption" rests. When consumers are incompetent or uninformed, or 
markets behave noncompetitively, regulation of consumer transactions usually is justifiable. ${ }^{6}$ Reasons to regulate drawn from the failure of the presuppositions on which the enforceability assumption rests are called "contract law reasons." As an example of their application in this contert, a court could use the anconscionability doctrine to strike down a broad security interest clause that is written in fine print and arcane legal language. ${ }^{7}$ Although no contract 1 aw reasons to support nonenforcement may exist, other reasons of fairness or utility al so may require regulation in particular cases. A second set of reasons justifying the regulation described above thus may derive from the peculiar nature of security interests in consumer goods.

Individuals, that is, may be unjustifiably disadvantaged by the giving of security in ways that do not disadvantage business debtors. This second set of reasons has been most influential in actualy causing decisionmakers to regulate security interests in consumer goods, and is the subject of this paper. 8

The reasons in this second set are: (i) Secured creditors are said systematically not to maximize the value obtained on resale of the collateral because these creditors can sue for deficiency judgments. For example, if the unpaid debt on default is 81,500 and the collateral has a fair market value of $\$ 1,000$, a secured creditor, it is claimed, will sell the collateral for less than 81,000 and sue for a deficiency in excess of 8500 . The Uniform Commercial Code prohibits this practice and gives debtors a cause of action should it occur. 9 The UCC's sanctions, however, are said to be inadequate; al ternatively, consumers allegedly lack the resources or sophistication to use the Code's protection. In either case, further regulation, such as banning deficiency judgments, is thought necessary. (ii) Repossession "destroys value" because individual debtors commonly value goods in excess of their market prices but corporate creditors at best resell at these prices. Because repossession imposes greater harms on debtors than it creates gains for creditors, cases exist against it on both utilitarian and fairness grounds. (iii) Creditors seldom repossess in order to reduce the size of the unpaid debt with the proceeds of the collateral because these proceeds of ten are trivial. Instead, creditors take security to enable them to coerce payment by threats to repossess. This coercion sometimes causes consumers to pay fets that are neither legally nor morally owing. Such "in terrorem repossessions" are wrongful.10 (iv) Enforcing broad security interests may violate some inalienable right of debtors to retain the property at issue. An ontrammeled power to repossess could enable creditors to detrive persons of goods that may be necessary to their leading of full and autonomous lives. Because people have a right to lead such lives, security can violate their rights. This property rights theme is more hinted at than discussed but seems an important influence. It apparently explains such justifications for regulation as that full enforcement of security interests in consumer durables "would cause too great a personal hardship." 11

Some of these reasons for regulation would be onpursuasive if 
consumers were perfectly informed respecting the strategies that creditors pursue. For example, if consumers knew that some creditors would not maximize the value of repossessed collateral, and if consumers could conveniently monitor creditor promises to maximize, creditors would have an incentive to make such promises. The market could cause creditors to compete along the dimension of transaction fairness, as well as along the more familiar dimensions of price and quality. Consumers, however, are not perfectly informed about creditor strategies. This paper thus assumes that the only postdefault creditor strategy of which consumers are aware is that secured creditors will repossess; ${ }^{12}$ the paper then argues that even given such 1 imited knowledge, the four reasons just set forth cannot justify regulating security interests. The law applicable to security interests in consumer goods should therefore be drawn from contract law doctrines. The practical importance of this conclusion is that contract theories suggest a different form of regulation than is now used. For example, unconscionability decisions traditionally are made case by case. Alternatively, a legislature might choose to regulate security in the way warranties are now of ten regulated; that is, it may attempt to create conditions that help ensure the existence of security agreements that benefit both parties to them by, for example, permitting enforcement only of those security interest clauses that are set forth in "clear and conspicuous" language. 13 Broad statutory prohibitions, however, such as those banning deficiency judgments, are justifiable only by the second set of reasons just summarized; because these reasons are unpersuasive, prohibitions of this sort should not be used.

Part I briefly describes the principal legal 1 imitations on the taking of security. Part II shows that creditors have incentives to maximize the proceeds from resale, and that the scanty available evidence suggests that they do so. Part III argues that no value is lost through repossession or that value is merely transferred; if either outcome occurs, the "value destruction" case against security falls. Part IV next argues that in terrorem repossessions are less common than is generally supposed, and that they are not objectionable when their effect is understood. Finally, Part $V$ argues that the moral theories underlying the objection that security violates persons' property rights may accord people rights to things but cannot sustain present limitations on the power of people to mortgage those things. In consequence of these arguments, this paper concludes that contracts to give security interests in consumer goods pose only the problem that consumer contracts generally pose, which is that the consent of consumers to them sometimes may not be fully free. ${ }^{14}$

I. THE LAW

Section 9-507(3) of the Uniform Commercial Code provides that "every aspect of the disposition [ $c_{i}$ collateral by the secured creditor] including the method, manner, time, place and terms must be commercially reasonable." Resale "may be by public [i.e. auction] or private proceedings"; in either case, "reasonable notification" of the 
sale must be sent to the debtor. The secured party is liable to the debtor for "any loss" caused by a failure to comply with Article 9. Also, if the collateral is consumer goods, the Code imposes a penalty on a creditor who fails to resell in a commercially reasonable manner, independently of whether the consumer debtor suffered loss: the noncomplying creditor is liable for "the credit service charge plus ten percent of the principal amount of the debt... plus ten percent of the cash price." 15

These Article 9 rules respond only to one of the grounds that could justify regulation of security interests in consumer goods, that creditors systematically fail to marimize the collateral's value. The rules, however, may be thought not to create sufficient incentives for creditors to maximize. This is partly because section 9-507(2) provides that a sale cannot be found unreasonable just because "a better price could have been obtained by a sale at a different time or in a different method"; rather, the price obtained is only one of the factors relevant to ascertaining reasonableness. This latitude could make it difficult for a debtor to prove that his creditor actually made a nonmaximizing resale. In addition, many consumers may lack the resources and sophistication to police compliance with Article 9.

Largely in consequence of these felt difficulties, courts have insisted on strict compliance with Article 9 procedures, in particular the notice of resale requirement, and have created their own sanctions to deter creditor misbehavior. The principal sanctions are: (a) in some states, to deny a deficiency judgment to a creditor who fails to comply with the Code ${ }^{16}$ (b) in other states, to impose on the noncomplying creditor the burden of proving that the collateral actually was worth less than the unpaid debt. ${ }^{17}$ A creditor who cannot show that the collateral was worth less than the unpaid debt has no grounds on which to claim a deficiency. In addition, courts occasionally require creditors to explain large differences between resale prices and the collaterals' apparent value, even when a debtor fails to prove creditor noncompliance with the statute. ${ }^{18}$

These judicial additions to Article 9 respond only partially to the concerns that onderlie the "failure to maximize justification" for limiting the ability of consumers to grant security. For erample, suppose that a group of automobile dealers in a given locality agrees to sell repossessed cars to each other at less, but not excessively less, than fair market value; however, when each dealer repossesses, he gives his debtor the requisite Article 9 notice and otherwise apparently complies with the statute. Few consumer debtors have the resources to prove that such a cartel exists yet without such proof the judicial sanctions just set out could not be imposed. Also, Article 9, even as supplemented by the courts, is not at all responsive to the concerns that commercially reasonable resales can destroy value, be used for in terrorem purposes or violate persons' property rights. Additional regulation of security interests in consumer goods thus seems necessary and exists.

The Oniform Consumer Credit Code 1 imits sellers to the taking of purchase money security interests, which secure the unpaid portion 
of the sales price. ${ }^{19}$ Also, when this price is 81,750 or 1 ess, the creditor is put to an election; if he repossesses, he cannot sue for a deficiency while if he foregoes repossession to sue on the debt, he cannot attach the goods in which he has a security interest. 20 Fina11y, the DCCC authorizes courts to prevent enforcement of a security interest that a lender takes in household goods if nonenforcement "is necessary to avoid undue hardship for the consumer or a member of a family .. supported by him." 21 Other states regulate more simply. California bans deficiencies in sales finance transactions for automobiles; ${ }^{22}$ Washington bans deficiencies in all sales finance transactions but not for loans; ${ }^{23}$ and New Mexico bans deficiencies altogether in consumer credit transactions. ${ }^{24}$ In addition, the Federal Trade Commission recently developed a proposed Trade Regulation Rule that would prevent creditors from taking security in household goods, except purchase money security. ${ }^{25}$ This Rule would also ban deficiency judgments in connection with purchase money security unless "the debtor is credited with the fair market retail value of the collateral as determined by a sale in an established retail market."26

These rules respond in different ways to the four justifications for regulation set forth above. Banning security is responsive to all of them. Banning deficiency judgments responds to the first justification, that creditors fail to marimize the proceeds obtained on foreclosure, because it limits creditors to these proceeds, and thus creates a strong incentive for creditors to marimize them. The proposed Federal Trade Commission Rule also responds to the failure to maximize justification. This is because fair market retail value is the most the collateral could yield; requiring creditors to reduce the outstanding debt by this value creates an incentive for creditors actually to obtain it. The ban on deficiency judgments also discourages the taking of security when the collateral is worth little in relation to the debt. It is in this case, it is shown below, that the latter three justifications seem most compel1ing. 27

Article 9 apparently responds intelligently to the occasional cases of creditor venality or sloth that will inevitably arise. The judicial additions to it and the recent statutory and administrative regulation just described presuppose the validity of one or more of the four justifications for regulation 1 isted above. It is to these justifications that attention must be paid.

\section{CREDITORS DO NOT FAII TO MAXIMIZE}

Many items are repossessed and resold each year. Because persons sometimes are careless or 1 azy, some of these items would be sold at less than their best price even if creditors sought to maximize resale proceeds. This fact cannot support the legal reforms just described because any system is subject to occasional human errors. Supporters of these reforms thus must make the stronger claim either that factors exist that systematically prevent secured creditors from marimizing resale proceeds although they want to do so 
or that secured creditors have incentives not to marimize. No systematic factors seemingly prevent creditors from maximizing if they choose to do so. Perhaps because of this, reformers claim that creditors have no incentive to maximize and that the evidence indicates that nonmaximizing resales are common. Part II shows that it would be irrational of secured creditors wishing to maximize profits to fail to maximize resale proceeds so long as each creditor does not act in concert with other creditors. A failure to marimize is a profitable strategy for creditors only if creditor cartels are assumed. Part II goes on to argue that creditor cartels to depress the resale prices of collateral are unlikely to exist. Before reaching the justification of these conclusions, it is worth stressing what claim actually is to be made below and the "deeper" assumptions on which this claim rests. The claim is that profit maximizing creditors have incentives to maximize resale proceeds and to eschew cartels. The deeper assumptions on which it rests, neither of which is defended here, are: (i) creditors act as if they attempt to maximize profits or, what is the same thing, share values, and ( $i i)$ by and large, people act effectively in pursuit of their goals, which means here that creditors will maximize resale proceeds if maximizing would be their most profitable strategy.

\section{A. Creditor Incentives}

The Federal Trade Commission Staff Report on the Proposed Trade Regulation Rule described above concisely summarized the claim that creditors systematically fail to marimize:

The creditor does not necessarily have an incentive to obtain the highest possible price for the collateral. There are a number of reasons for this, including [1] the fact that Article 9 of the OCC which requires that any surplus be repaid to the consumer imposes a ceiling on the return available to a creditor in a repossession sale. [2] At the same time, the fact that a deficiencies [sic] can be collected from consumers in many cases tends to mitigate any necessity of maximizing the repossession sales price. [3] Moreover, any loss to a creditor in the form of an uncollected deficiency is mitigated by immediate tax benefits which tend to reduce the amount of the actual loss by 50 percent. 28

The report explained, in connection with the second reason given:

In the area of high priced collateral, creditors will invest in a repossession sales effort only to a point where the net return from the repossession sale equals the net return from resources invested in the collection of deficiencies. Thus, where the right to collect deficiencies exists, a lesser sales effort is a reasonable expectation. 29

Respecting the first of these reasons, creditors do lack an incentive to maximize the surplus-the excess of the collateral's resale price over the unpaid debt-because the surplus accrues to debtors. The 
perceived problem that prompted the legal reforms described above, however, was not that resales generated insufficient surpluses; a surplus is rare when consumer goods are resold. Decisionmakers were instead concerned with the possibility that nonmarimizing resales increased the deficiencies that consumers had to pay. Moreover, if creditors actually do maximize the proceeds received from resold collateral when its value equals or is less than the outstanding debt, the problem of insufficient surpluses should vanish. This is because creditors commonly set op systems whereby repossessed collateral is sold. If these systems are designed to maximize resale proceeds, because the collateral commonly is worth less than the unpaid debt, the occasional surplus will al so be maximized; for it seems irrational of creditors to expend the resources necessary to identify collateral likely to bring a surplus and then to vary the standard routine only for the purpose of reducing the surplus. While creditors, that is, have no incentive to maximize the value of surploses simpliciter, they al so have no incentive to vary standard practice solely to disadvantage consumers. Thus, where standard practice is to marimize, surpluses al so are likely to be marimized.

When the collateral will bring less than the unpaid debt, standard practice allegedly is not to maximize because of the availability of deficiency judgments, the second reason the FTC staff gave, but this reason is false. If secured creditors maximize profits and do not act in concert with other creditors, each creditor mast do worse by not maximizing resale value than by maximizing it. An example makes this point.

Suppose a secured creditor sells a new car to a debtor who makes several payments and defants. Let the unpaid debt be 85,000 ; the value a maximizing resale of lis car would bring be 83,000 ; the value of a nonmazimizing resale be 81,500 ; the probability, as observed by the creditor, that the debtor will become (or is) insolvent be twenty percent (.2). Also, suppose the creditor would collect 8.12 on the dollar if the debtor did become insolvent and entered insolvency proceedings, 30 and that the discount rate is zeroto the creditor, a dollar received in sir months is worth as mach as a dollar received today. What is the expected value to the creditor of maximizing the proceeds of resale? And what is the expected value of not maximizing?

\section{Marimize}

Total Expected Recovery $=\$ 3,000$ (from resale) +

$.8(\$ 2,000)$ (expected value of deficiency judgment if collected in $\mathrm{foll})+$

$.2(\$ 2,000 \times .12)$ (expected value of deficiency judgment if debtor goes bankrapt $)=\$ 4,648$.

2. Don't Marimize

Total Expected Recovery $=\$ 1,500$ (from resale) +

$.8(\$ 3,500)+$

$.2(\$ 3,500 \times .12)=\$ 4,384$. 
The example shows that the expected value to the creditor of failing to marimize the car's resale value is 8264 less than the expected value of maximizing it. A proof in the appendix generalizes this example; ${ }^{31}$ whenever the probability that the debtor will go bankrupt is positive (greater than zero), the expected value of failing to maximize the proceeds of resale is always less than the expected value of maximizing. Al so, the example supposed the discount rate to be zero bat this is false; a dollar received today is worth more than a dollar received in sir months because the dollar received today can be invested in a riskless asset sach as a Treasary bill that yields a sure return. Suppose then, in the example above, that a creditor can collect a deficiency judgment no sooner than three months after resale of the collatera1; that he can collect in insolvency proceedings no sooner than sir months after resale; and that the interest or discount rate is 8 percent. Then the expected value of failing to maximize is $\$ 289.96$ less than the expected value of maximizing.

These examples suppose collection costs to be zero for ease of exposition. The FTC staff's explanation cited above, that creditors will compare the costs and gains of various collection devices, correctly focuses attention on costs, but the conclusions based on these examples are unlikely to change if the zero cost assumption is relaxed. To see why, suppose, again for ease of analysis, that the creditor's fired cost is zero; his marginal collection costs are constant at 8.20 per dollar collected on resale, but only 8.10 per dollar collected in a deficiency action or in a bankroptcy proceeding; and that each party bears his own attorney's fees. These examples are meant to make resale twice as costly as a suit for a deficiency. The first example above, with the discount rate at zero, becomes:

1. Maximize :

Total Expected Recovery $=(83,000-8600$ cost of resa1e $)+$ $.8(\$ 2,000$ debt plus $\$ 600$ resale costs recoverable in deficiency action -

$\$ 260$ cost of collecting deficiency) +

$.2(\$ 2,600 \times .12-\$ 31.20$ cos" of collecting

in bankruptcy) $=\$ 4,360.16$

2. Don't Maximize:

Total Expected Recovery $=\$ 4,322.08$

When it is twice as expensive to resell than to collect a deficiency, the expected value of maximizing still exceeds the expected value of not maximizing by 838.08 . In $\mathrm{fact}$, the cost of collecting deficiency judgments is likely to exceed the cost of repossession and resale because foreclosure often can be done quickly by salaried employees, withont the necessity for paying counsel or court costs or waiting to collect the money. Thas the basic conclusion is unaffected by considering costs; it always pays creditors to maximize. 32

The se examples also illustrate the error of the third reason the FTC Staff gave to explain why creditors woold not maximize, that a creditor's concern over an unpaid deficiency judgment is mitigated by 
his ability to dedact bad debt losses. In the second example above, where the discount rate was positive, the expected after tar loss to the creditor who maximizes the proceeds of resale, supposing a marginal corporate tax rate of 44 percent, is 8213.37 ( 85,000 unpaid debt less $84,618.99$, the expected value of collection, leaves an expected tax deduction of 8381.01 , which with a 44 percent marginal tax rate imposes on the creditor an after tax loss of .56 I the dedaction). The expected after tar loss to the creditor who does not maximize is higher-\$379.74, a difference of 8162.37 . This result is not surprising because the effect of the tax is to enable a corporate creditor to keep 8.56 of every dollar it earns, and to benefit by 8.56 from every dollar it dedacts, supposing it to have income. Thus the creditor cannot gain by foregoing income, which loses it 8.56 per dollar, in order to increase dedactions, for these gain it only 8.56 per dollar. A creditor therefore will regard the availability of tar dedactions as irrelevant to its decision whether to marimize or not. ${ }^{33}$

\section{B. Wholesale Sales}

Financial creditors such as banks and finance companies frequently sell repossessed collateral in wholesale rather than retail markets. Because retail sales generate higher returns, the practice of wholesaling repossessions is thought to disadvantage consumers.

Moreover, the practice of some creditors to make wholesale sales when retail markets are available is considered strong evidence in support of the claim that creditors systematically fail to maximize the value of repossessed collatera1. 34 In consequence of these views, proposals have been made to require or encourage retail sales in all cases. An example of such a proposal is the FTC's suggested rale that roold permit wholesale sales but require financers to credit consumers with the amount that actual good faith retail sales would bring. ${ }^{35}$ The Commission staff apparently thought their role woold work in the following way: Let a bank repossess a car on which 88,000 is owed and sell the car to a dealer for 84,000 . The dealer retails the car for 86,000. Under the proposed role, the bank must credit the debtor with the amount that the retail sale brought- 86,000 -and thas coold sue only for a 82,000 deficiency. Since the bank woold then incur a $\$ 2,000$ loss, banks are 1 ikely to sell at retail if the role is passed. Whether they do or not, consumers will benefit because they will be liable for lower deficiencies.

The examples in Part II A above showed that creditors always do better by maximizing resale proceeds. Consumers do better as we11, becase a marimizing resale reduce the deficiency that the debtor owes. In the example just used, however, a bank chose to resell at Wholesale, recovering 84,000 , rather than at retail, whereby 86,000 could have been obtained. This example does not refute the analysis above when resale costs are considexed. Part II B next shows, through a more carefol analysis of this example, that a profit marimizing financer probably would want to wholesale his repossessions.

It is best to begin by focusing on the difference between the wholesale and retail prices-the $\$ 2,000$ premium in the illustration 
above. This premium has two elements: (i) the cost of patting a repossessed car in shape for resale; (ii) a payment to the retail dealer, including the dealer's profit, for the service of ronning a retail business. Part of the premium, that is, helps the dealer defray the costs of a showroom or sales lot, a repair capability and sales personne1, and provides a retorn on the capital invested in the basiness. Since the retail dealer cannot condact his business unless he is able to bay at wholesale, a portion of the deficiency judgment-$\$ 2,000$ hero-actually supports the retail facility.

Suppose that the bank, in this illostration, instead retailed its repossessions. To do so, it would need a retail facility. If the bank had the same retail costs as the dealer and resold for 86,000 , it would be able to sue for a $\$ 4,000$ deficiency under the Code, calculated as follows: Deficiency = unpaid debt $(\$ 8,000)$ - proceeds of resale $(\$ 6,000)+$ costs of resale $(\$ 2,000))=\$ 4,000$. To deny the bank the 82,000 in resale costs woold be to require it to provide a retail facility for free. 36 Thus if banks and dealers conld retail cars at equal cost, both banks and consumers would be indifferent to Whether banks wholesaled or retailed; either method woold generate the same deficiency.

Dealers, however, commonly can retail repossessed cars at less cost than banks or finance companies because financers have expertise in the lending business but not in the selling ased goods business, while dealers commonly have the reverse competencies. 37 When the financer's cost disadvantage is considered, the error of encouraging financers to become retailers becomes apparent. Suppose that it would cost the bank in the illustration above $\$ 2,200$ to retail the car rather than the 82,000 it costs the dealer. A retail sale then roold net the financer $\$ 3,800-\$ 6,000$ in proceeds 1 ess $\$ 2,200$ in costs. A wholesale, however, nets 84,000 . Thus when financers are less efficient retailers than dealers, which often seems the case, a Wholesale sale is value maximizing. Because this is so, the common practice of financers to make wholesale sales cannot count as evidence in support of the claim that creditors systematically fail to marimize the value of repossessed collateral. In addition, efforts such as those of the FTC's staff to coerce financers to retail repossessions would disadvantage debtors by increasing the deficiencies for which debtors would be 1 iable. In the illustration above, the deficiency would increase from $\$ 4,000$ to $\$ 4,200$ were the FTC rale to apply.

To summarize the argament to this point, secored creditors who wish to marimize profits and who do not act in concert with other creditors always will do better by maximizing the proceeds from resale of the collateral. The common practice of financing creditors to wholesale repossessions does not contradict this conclusion. The failure to maximize justification for 1 aw reform therefore mast fall unless cartels exist.

\section{Carte1s}

Two related kinds of cartois might exist respecting repossessed goods. First, a group of dealers could agree to bid 
collusively on repossessed items offered for sale such that each dealer is assured a supply of low priced goods, which can then be resold at retail prices. In this circumstance, the repossessing creditor-suppose a bank-conld actually be attempting to maximize the resale value of the collateral but be prevented from doing so by the dealer cartel. "Collusive bidding cartels" might exist in connection with pablic resales, when repossessed items are sold at action. Second, a group of dealers who carry their own paper or who are involved in recourse financing arrangement $s^{38}$ might agree to resell collateral to each other for less than the collateral's value. For example, suppose dealer A repossessed a car worth $\$ 3,000$ when the unpaid debt was 85,000 , sold the car to dealer $B$ for 81,500 , and sued for a 83,500 deficiency. Part I A showed that this was a losing strategy. But suppose dealer A knew that dealer B would resell it a repossesed car for $\$ 1,500$ less than its actual value shortly thereafter. Then dealer $A^{\prime} s$ expected loss from failing to marimizo8289.96 in the principal example above-is swamped by his expected gain-the large difference between the retail price of the car later to be purchased from dealer $B$ and the low wholesale price that dealer B will exact. Because any two dealers are unlikely to have precisely matching repossession experiences, a "dealer trading cartel" such as this would need several members, al though probably fewer than the collusive bidding cartel described above. 39

The gain to participants in both of these cartels comes from being able to buy repossessed goods at artificially depressed wholesale prices and to resell them for full retail value. Because banks and major finance companies sell repossessed goods bat never bay them, these financers have no incentive to join either cartel. Indeed, the financers would oppose collusive bidding cartels because these cartels reduce the returns from repossession sales. And dealer trading cartels would seldom be marketwide because financers can compete with dealers to finance sales. The question is whether either form of cartel can function in these circumstances.

This is an empirical question that cannot be finally answered on the available data. No persuasive evidence of the existence of either form of cartel has been adduced, nor have any been successfolly prosecuted. These facts are not conclusive. Successful cartels seldom are revealed by academic inquiry. Also, academic inquiries must use poblicly available data, such as profits and price movements. Outsiders cannot easily obtain profit figares for the sma11, often privately held firms that will constitute any cartel; and actual transaction prices of used goods are difficalt to observe. These problems would make hard evidence of the existence of cartels unisual even if the cartels themselves were common. In addition, cartels in conection with the resale of used consumer goods will occur-if at a11-in local markets, and state antitrust enforcement is seldom vigorous. Thas little can be inferred from the absence of prosecutions against them. With the record in this state, the best that can be done is to ask whether the industry or firm traits that seemingly correlate $w$ ith collusive behavior exist when repossessed 
collateral is resold. If these traits exist in insufficient degree, as is argued below, the burden should shift to proponents of the "failure to maximize" justification for law reform to prove that creditor cartels are in fact present. This is because, as shown above, without cartels such as those described here the failure to maximize justification must fall. The discussion focuses mainly on used car markets becanse creditor misbehavior is said to be most prevelant there. 40

\section{Collusive Bidding Carte1s}

The 1 ikelihood that firms will cartelize an industry varies inversely with the costs to the firms of making and policing collusive arrangements, and varies directly with the ability of firms to retain significant gains from cartel behavior. Several more specific factors that seemingly correlate positively with the existence of cartels have been derived from these general observations. Firms will incur relatively lower costs in forming and policing cartels when fer firms exist because it is easier to make lasting arrangements among few than among many. Also, cartel costs are lower when firms deal in homogeneous goods because then the only variable on which agreement mast be secured is the price. Respecting the ability of firms to retain gains from cartel behavior, cartel members have an incentive to steal customers from one another by offering buyers prices below the high cartel price but above the competitive price; if many members act in this way, the cartel will dissolve because firms that adhere to cartel arrangements would have no customers. The opportunities for cheating are lower when all sales are made publicly, so that the terms are observable; when firms have large market shares, so that the expansion of firm outpot that cheating produces is noticable; and again when product and sales terms are homogeneous, so that firms cannot grant difficalt to detect nonpecuniary price reductions such as more extensive warranties. Finally, the ability of firms to retain gains from cartel behavior is higher when entry into the industry is difficult. Were entry easy, outside firms have a strong incentive to come in and steal cartel customers by undercutting the cartel's price. The prospect of such entry condd redace the expected gain from cartelizing below the expected cost; in this event, a cartel is unlikely to be formed. ${ }^{41}$

These factors saggest that effective collusive bidding cartels among dealers to depress the prices at which collateral is resold should rarely exist in markets for repossessed consumer goods. One factor that actually does increase the probability of such a cartel is the ease with which cartel members conld detect cheating. To see why, suppose the antomobile dealers in a town agree to make low bids on the repossession sales of the local banks. Each dealer has an incentive, at any particular auction, to cheat by bidding an amount above the $10 \mathrm{w}$ cartel price but below the actual wholesale value; in this way, the dealer can boy cars at very low prices when the cartel allows him to be successfal bidder and to buy at below market anyway when the cartel has chosen someone else. Such cheating would be simple to detect and 
deter because bids at resale anctions are public. Thas the cartel conld discipline the offending dealer relatively easily; for example, it cond always overbid him at actions to shat off his supply. The remaining relevant factors, however, point against the existence of collusive bidding cartels.

Initially, cartel arrangements would be costly to make. First, relatively large numbers of dealers exist in many local markets; used car sales, for example, are made by new car dealers and by used car lots, both of which commonly sell a wide variety of mode1s. Also, most--perhaps-a11-firms in a market must be members or a collosive bidding cartel conld not survive. This is because a very few firms coold destroy a cartel by overbidding at pablic actions, which nonmembers woold have a strong incentive to do. In consequence, a successful cartel would require the agreement of a substantial number of firms, having different business experiences and of different sizes. As an example of the difficalties firms cond experience in reaching agreement in these circumstances, consider the problem of creating an allocation, among members with different business experiences, of the number of 10 priced cars that each is entitled to bay per period. The existence of product heterogeniety will increase the costs of reaching such an agreement. A large variety of repossessed antomobile models will be offered for sale at any one time, differing from each other by make and style as well as age and physical condition. Thus the actual problem that potential cartel members face is not merely to create a numerical allocation of cars to firms, but to create a prise schedole for the cars that are likely to be offered, and then to allocate cars among firms by number and type. A lasting agreement of this sort seems more costly to obtain than did the agreements in Eost reported cartels. ${ }^{42}$ Cartel members also woold have difficulty retaining significant gains from collusive behavior because entry into the used car business is relatively cheap. An entrant needs primarily to lease a lot and boy cars, which in this case can be done relatively easily because the cartel will have artificially depressed the prices.

Indeed, financing for the purchase of these cars may be obtained more easily than usual because the banks and finance companies will be hart by the cartel; thas they may more readily finance its downfall. Further, entry can be by existing firms in other markets. Used car markets are at least regional in scope at the wholesale level. If a cartel in a particular local market has depressed prices by more than the difference between the wholesale price and shipping costs to nearby markets, firms in these markets will enter to bid the price op. Repossessing creditors such as banks have an incentive to notify outside firms of favorable opportunities for entry. The relative absence of barriers to entry in used goods markets, in contrast to other markets in which cartels have been successfal, suggests strongly that collusive bidding cartels are unlikely; the incentive of existing firms to join them should be overborne by the inability of these firms to protect their gains against erosion cansed by the entry of new firms. 
In addition, two factors peculiar to used goods markets--in particular markets for antomobiles--al so suggest that such cartels will not exist. First, financers often can avoid the effect of strong collusive bidding cartels by refusing to make parchase money loans to consumers. If this is done, dealers woold have to extend credit themselves and sell their paper to the financers. The financers could then insist on recourse arrangements such that if the consumer defaults, the dealer mast pay the financer and himself collect the debt. In such an arrangement, the dealer resells the car. To be sure, recourse financing is more costly to financers than direct consumer loans when such loans are routinely made, but probably woold be less costly than remaining supine before an effective collusive bidding cartel. In consequence, the expected gains to dealers from cartelizing are limited not only by the potential entry of new and eristing dealers bot by the ability of the financer sellers to withdraw from the market by altering the way in which they finance consumer transactions.

The second factor peculiar to these markets that makes collusive bidding cartels less 1 ikely is that the potential colladers often ose external financing to maintain their inventories. These dealers need the good will of at least some financers; as a result, the financers sometimes have a weapon with which to force the dealers to bid the collaterals' actual value. Cartels generally are more difficalt to maintain when the sellers are numerous and relatively small and the buyers few and large. The difficulty occurs because the large buyers can exercise countervailing power, by playing the sellers off against each other, strategically withholding orders and so forth. ${ }^{43}$ In the consumer goods case, it is the dealer boyers who are numerous and relatively small and, often, the financer sellers who are few and large. The financers tend to be banks and large finance companies such as GMAC. Bat the principle seems the same; the fer large sellers sometimes could use weapons such as their ability to withhold financing to exercise effotive countervailing power against the numerous small dealers.

To summarize, the factors that correlate positively with the existence of cartels are not present in sufficient degree to justify a conclusion that collusive bidding cartels influence the prices at which repossessed collateral is sold. As indicated above, little direct evidence of such cartels exists. ${ }^{44}$ Respecting indirect evidence, casual surveys of antomobile repossessions show that financing creditors recover approrimately 80 percent of the "wholesale value" of the cars they se11. 45 This wholesale value represents a prediction by knowledgeable observers if the selling prices of used cars in salable condition at the beginning of each car's model year. At least part of the apparent 20 percent discount off wholesale value is accouted for by three factors: (i) the expense of putting repossessed cars into salable condition; 46 (ii) the fact that used cars are offered for sale throughout the year; and (iii) the inability of financers to offer quality garantees because they lack the facilities to diagnose defects or service warranties. Any unaccounted 
for difference between book and actual wholesale prices seems too small alone to support the inference that collusive bidding cartels must exist because creditors recover so little in repossession sales.

\section{Déaler Trading Carte1s}

In dealer trading cartels, a relatively small group of dealers resell repossessed cars to each other at less than wholesale prices. These cartels are easier to create and maintain than collusive bidding cartels in some respects but not in others. On balance, they too are unlikely to exist. The first factor used above concerned the costs to firms of cartelizing behavior. A dealer trading cartel needs fewer members than a collusive bidding cartel; a few firms with similar repossession experiences, so that they can confer similar reciprocal benefits on each other, seemingly would suffice. The effective cartel size, however, often will exceed two. In this event, the problems of numbers and heterogeniety should make it difficalt to devise an allocation and a pricing stracture.

In addition, the members of dealer trading cartels must al so consider the effect of debtor defants. To see why, recall the hypothetical in Part I A above-where the debtor defaulted with an unpaid debt of 85,000; a maximizing resale woold bring 83,000; a nonmarimizing resale wonld bring 81,500 ; and creditors conld recover twelve cents on the dollar in insolvency proceedings. On these facts, the creditor's expected loss on defant was $\$ 264$ greater if he failed to maximize than if he maximized, when the probability that the debtor would enter insolvency proceedings was .2. If the probability of insolvency were .6 , the expected difference between not maximizing and maximizing rises to 8792 . In this latter case, the failure to maximize woold be a winning strategy only if the creditor conld make an offsetting purchase from the cartel at a much 10 wer price than the creditor would need to make when the probability of insolvency was .2 . To be specific, if the expected negative difference from failing to maximize is 8290 , the creditor $w i 11$ gain if he can by a repossessed car from the cartel for $\$ 300$ less that its wholesale market value; if the expected difference rises to 8700 , the creditor must obtain a much greater discount off the wholesale price. Because of the 1 inkage between debtor insolvency probabilities and the prices at which dealers would want to buy collateral from each other, cartel members world have to reach agreement on the impact that each member's bad debt experience should have on the cartel's allocation and pricing structure. An agreement of this sort is hard to reach. ${ }^{47}$ And this difficulty added to the ones described above suggest that it would seldom be cheaper for firms to create dealer trading cartels than to create collusive bidding cartels.

In addition, dealer tradin greater opportunities to cheat. To see why, consider the forms of cheating that conld occur. Initially, firms have an incentive to 1 ie about their bad debt experiences when participating in the creation of periodic allocations of parchases they make from and sales they make to the cartel. Each cartel member has an incentive to parchase goods 
from the cartel at very 10 wholesale prices but to retail these goods at market value. Members would justify making many $10 \mathrm{w}$ price parchases by claiming that their debtors are quite likely to become insolvent; in such cases, we have seen, the expected loss from making 10w price sales-from not marimizing-is high, so the ability to make 10 price parchases is essential to profitability. In a related vein, cartel members have an incentive to sell goods to the cartel at high prices because, respecting each individaal defaul, the higher the price obtained on resale the 10 er is the expected loss. Members would justify making high price sales by claiming that other members' debtors probably can satisfy deficiency judgments in full; when this is the case, a dealer woold lose relatively little from making low price sales and thas woold not need to make many 10 price purchases.

The probability that a given firm's debtor will enter insolvency is difficult for outsiders to assess and is excessively costly for the firm to establish convincingly to outsiders. This is because this probability must be inferred largely from the particular circumstances of an individaal debtor who has defanted rather than, as in the original credit extension, from characteristics the debtor has in common with many other consumers. Pat another way, the question whether a person is creditworthy is more likely to be made on objective factors, while the question whether a person who has missed payments is likely to drown or recover is more 1 ikely to be made on individual, sabjective factors. In consequence, cheating in the form of members attempting to make too many $10 \mathrm{w}$ price purchases from and too few 10 price sales to the cartel is likely to be common and difficalt to stop. In addition, each cartel member has an incentive to sell some items at full wholesale value to nonmembers, but to continue making $10 \mathrm{w}$ price parchases from the carte1; for a creditor who maximizes resale value on his own repossessions but is able to parchase goods at artificially depressed prices will do better than "honest" cartel members, who necessarily mast make many low price sales as well as low price purchases. Because sales to outsiders can be made privately and because a dealer probably can conceal or explain a failure to make numerous sales to the cartel, at least for a time, cheating in the form of selling goods to ontsiders is also likely to occur, especially by dealers who are facing hard times that they consider temporary. The strong incentives to cheat that dealer cartel members have together with the apparent ease with which cheating can be done suggest that dealer trading cartels would be quite unstable. The remaining relevant factors are more consistent with the existence of these cartels, but seemingly not to a significant extent. Entry of new dealers would be less likely to disrupt particular cartels because potential entrants would have difficolty knowing whether cartels actually existed. On the other hand, if cartelization generated excess profits in parti:ar : markets, new firms probably would enter these markets because entry costs are 10w. The general downard pressure on price that such entry would cause is a disincentive to form cartels initially. The special factors noted above that made collusive bidding cartels unlikely would not operate 
against dealer trading cartels, for those factors all were motivated by the ability and incentive of the financers injured by cartel behavior to oppose that behavior. Dealer trading cartels do not injure financers. Dealers, however, do compete with financers in offering credit to consumers. If dealers routinely begin to claim greater deficiencies than financers on otherwise similar loans, because of dealer trading cartels, dealer credit would become relatively more expensive than financer credit. Consumers woold then have an incentive to shift away from dealer credit; their ability conveniently to do this also redaces the expected gains to cartel behavior.

Dealer trading cartels, analysis suggests, thus seem not mach more 1 ikely to influonce the prices at which repossessed collateral is sold than are collusive bidding cartels. No direct evidence of the eristence of dealing trading cartels has been offered, nor is there indirect evidence. In particular, dealers seemingly do not claim larger deficiencies than financers on similar credit extensions, which woold occur if dealer trading cartels were common. 48 If a decisionmaker nevertheless believed that such cartels pose a danger, a legal remedy that would be as effective and less intrusive than the reforms summarized in Part I would be to require all sales to be public. Since nonmembers woold then learn of the sales, they coold overbid the cartel for repossessed goods, cansing the cartel to dissolve. The likelihood that dealers trading cartels exist, however, seems too low to justify incurring the costs that would flow from a complete ban on private sales. ${ }^{49}$

\section{Summary}

The belief that creditors systematically fail to maximize the value of repossessed collateral has been influential in causing decisionmakers to adopt or propose restrictions on the taking of security interests in consumer goods. Part II A has shown that creditors acting alone have incentives only to maximize resale value. Part II B then demonstrated that the practice of many creditors to wholesale rather than retail their repossessions is consistent with the view that creditors maximize. Indeed, requiring retail sales, as some have proposed, actually would cause debtors to pay higher deficiencies than they now do. Finally, Part II C showed that creditors conld do better by failing to maximize resale value if they could successfully cartelize resale markets. Part II C went on to argue that no porsusive evidence of the existence of creditor cartels exists, and that theory suggests their existence to be improbable. In consequence of this analysis, pablic policy should no longer be made on the assumption that creditors do not maximize; the assumption mast be the other way.

III. REPOSSESSION AND THE ALLEGED DESTRDCTION OF VALUE Coercive repossession is said to impose greater harms on debtors than it creates gains for creditors. This might occur in four ways. First, debtors may value goods in their possession at in excess 
of the goods' market price. For example, a consumer woold sell his stereo for no less than 8600 but its used goods price is 8500 . When the stereo is repossessed and resold for $\$ 500$, 8100 of value allegedly is destroyed. Second, the lack of effective resale markets may undaly depress the value of used goods. Suppose that the debtor's stereo woold be worth at least 8500 to anyone who knew how reliable it was, such as the debtor himself, but strangers would fear breakdowns and thas woold pay no more than 8400 for the stereo. The market price for used stereos is artificially depressed because owners know more about their goods than outsiders do. In this illostration, the information asymmetry canses a $\$ 100$ value loss because the repossessing creditor could sell the stereo for at most 8400 . Third, repossession conld destroy haman capital. As an example, the stereo may work perfectly if treated in a certain fashion that the debtor has discovered. When the stereo is repossessed and resold, the new owner mast take time to learn-if he ever does learn-how best to use it. In consequence, the debtor's investment in learning how to use his stereo is wasted.

Fourth, repossession may cause debtors to incur psychic losses that are not of fet by psychic or other gains el sewhere.

These harms conld not occur if debtors were perfectly informed of the consequences of granting security. This is because if security imposed greater expected harms on debtors than it created expected gains for crditors, the creditors could not parchase the consent of the debtors to grant security; rather, the debtors woold choose to pay higher interest rates. Information imperfections are believed to be common in consumer credit markets, however, and fall within the set of contract reasons that are not discussed here. Part III instead assumes that debtors when they borrow are ignorant of the possibility that repossession conld cause them to incur losses such as those just described.

If debtors are so uninformed and if these losses do occur, repossession would be morally objectionable. A legal institution that causes greater harms than gains is unsatisfactory on otilitarian grounds. Repossession also could violate the Kantian fairness principle that each person should be treated with equal respect and concern. This is because a creditor who will impose a 81,000 loss on a debtor to secure for himself a $\$ 300$ gain is treating the debtor's interests as of mach less significance than his own, apparently without a moral basis for the distinction. The question, then, is whether repossession actually does destroy value. Part III next argues, depending on the way in which repossession is alleged to impose harm, either that no social losses occur from it, or that no net social losses can be shown to occur, or that any net social losses that do occur are trivial.

The first form of the value destruction claim, that a debtor loses the difference between the value he attaches to the goods and their market price, seemingly assumes what is to be decided. To see why, let $P=$ the collaterals' used goods market price and $W$ be the price that the debtor woold charge to sell the collateral voluntarily. In the illastration that introdaced Section III, $P=8500$ and $W=$ 
8600; thus repossession imposed a $\$ 100$ loss on the debtor. However, one can "lose" only what one "owns." Suppose that the state had previonsly decided to confer on secured creditors the absolute right to repossess whenever a debtor defauted. Then the debtor seemingly would lose nothing from repossession because after default he would own nothing. The question, that is, apparently is whether creditors or debtors have a right to the collateral on defaul, and the initial version of the value destruction claim presupposed but did not justify an answer to this question; it simply assumed that debtors had the right.

This version of the value destraction claim can be stated in a nonconclusory way if a debtor who lacked the right to keep the collateral in the event of default would bid in excess of its market price to prevent repossession. Let $V=$ the price a debtor woold pay to keep the goods if he had no legal right to them. Then if $V>P$, the debtor incurs a value loss even though he lacks the property right. Proponents of this first (of four) versions of the value destraction claim seemingly suppose the losses that debtors incur from repossession to be nontrivial; in the terminology used here, they suppose $W-P$ to be 1 arge. If they are right, $V$ also is likely to erceed $P$. This is becanse the price which the debtor would bid for the right to keep the goods $(V)$ is unlikely to be very mach lower than the price the debtor would choose to sell the right (W), so that if the latter is considerably greater than the market price (P), the former will exceed the market price also. 50 In this event, the value destraction claim can be made out independently of where the property right is. The debtor's loss is $W-P$ if he owns the right and V-P if he does not, with both magnitudes exceeding zero. It is a separate question whether in fact both magnitudes are positive, but for now this is assumed.

A complete statement of the initial version of the value destruction claim mast also explain why a debtor who values goods at in excess of their market price roold ever defanlt. To understand this problem, let $D$ be the outstanding lebt, which is the unpaid portion of the price, with $V$ and $P$ being defined as above. Suppose the debtor's circumstances have changed after a sale such that he comes to believe that the goods are worth less to him than the unpaid price; for example, the debtor has become unemployed and would rather spend scarce resources on rent rather than stereo payments. In this event, the debtor has an incentive to abandon the deal because the goods are worth less to him than the outstanding debt $(D>V)$. Repossession would also disadvantage him. As an example, let $\mathrm{D}=$ 8650; $V=8590 ; P=8500$. If the creditor repossesses and rese11s, he will sue for $D-P=\$ 150$. If the creditor can sue only for the debt, the debtor's loss is the debt less the value of the goods the debtor retains-D $-V=\$ 60$. Thus repossession imposes an additional $\$ 90$ loss on the debtor, the difference between what the debtor would pay for the right to keep the goods and their used goods' price (V - P). This case probably is common because the market price of many consumer goods declines more rapidy after parchase than the atility that 
consumers derive from the stream of services the goods yield.

However, if the debtor believes with certainty that the creditor will sue for $D-P$, he seemingly would not default; rather, he would pay $D$, al though $D>V$, because this cuts his loss to $D-V$, which is 860 here. A debtor, though, could reasonably believe that his creditor will not sue because deficiencies are sought in a minority of cases. Also, if the debtor defants, he can use the money that would otherwise go to the creditor to meet immediate needs; the benefit of being able to do this may sometimes exceed the cost of later having to pay a deficiency judgment by means of a wage garnishment. For some persons, that is, default is a way of extending the payment period. 51

It is now possible to state the initial version of the value destruction claim completely: If (i) debtors roold ask a sum in excess of the collateral's used goods market price to allow a creditor to repossess on defanlt (W-P > O); or (ii) debtors would bid a sum in excess of the used goods market price to retain the collateral in this event $(V-P>0)$; and (iii) debtors routinely default when the atility they would derive from retaining the unpaid portion of the price exceeds the otility they would derive from retaining the goods (D > $W$ or V), then repossession causes debtors to lose value. Further, if (iv) creditors necessarily derive less value from repossessed goods than debtors lose and $(\nabla)$ repossession does not otherwise create value, repossession al so causes net social harms.

The latter two assumptions seem less likely to hold than the first three. Respecting assumption (iv), consider the repossessing creditor in his status as a seller of used goods. Firms are said to sell until marginal cost equals marginal revenue; the marginal unit, that is, brings in as revenue an amount equal to the cost of producing and selling it. Most units that are sold, however, are inframarginal; they bring in revenue in excess of cost. Suppose then that (a) the market price of a used item is $8505^{\circ}$ (b) the defaulting debtor would pay $\$ 590$ for the right to retain the item; (c) the product when repossessed and resold is inframarinal to the creditor, bringing in revenue of $\$ 120$ over costs; (d) the debtor and creditor have the same marginal atility for money. In this circumstance, repossession actually creates a net social gair; the creditor gains 830 of atility more than the debtor loses. Also, the creditor is not acting on the belief that costs imposed on the debtor are of considerably less concern than gains to him. In actual cases, it would be impossible to know whether repossession creates net social gains or losses. This is because the parties probably will have different marginal otilities for money, but these atilities as well as the debtors' bid and ask prices-the prices for which they would buy or sell the right to keep the goods--are unobservable. The point of the illustration rather is to show that the creditor's net gain from repossession and resale is not necessarily less than the debtor's loss.

Assumption ( $v$ ) above also is unlikely to hold because second buyers commonly value resold goods at in excess of their price. This point is made clearly with a graph. The curves S (supply) and D (demand) are for used goods at the time when the debtor decides that 
the goods are worth less to him than the unpaid portion of the price.

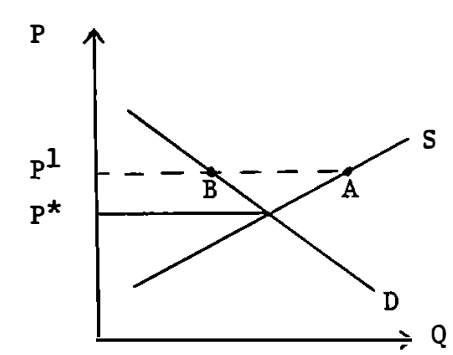

The debtor in this illostration is located at point $A$ on the supply curve $S$; this means, supposing him to have the property right, that he would not sell the collateral at its used goods market price, $P^{*}$, bot wonld sell if the price rose to $\mathrm{P}^{1}$. The difference between these two prices $\left(P^{1}-P^{*}\right)$ is the debtor's loss from repossession, in the sense at issue here. The second boyer is located at point $B$ on the demand carve $D_{\text {; }}$ this means that he would buy the product if its price were as high as $\mathrm{P}^{1}$. The difference between this price and the market price at which he is able to purchase $\left(P^{1}-P^{*}\right)$ is the second buyer's gain. In this illustration, these gains and losses are exactly offsetting, but they need not be; considering just the debtor and second buyer, repossession and resale could create net social gains or losses, depending on the valuation the parties attach to the goods.

Onfortunately, these valuations are unobservable, but the point is the same; repossession does not necessarily destroy value.

To summarize, if the debtor's loss from repossession is conceptualized as the difference between the price for which the debtor would bay or sell the right to keep the collateral and the collateral's market price, repossession woold create net social losses only if the debtor's loss typically exceeds the creditor's and second bryer's gain. Decisionmakers cannot know whether this is the case. From a atilitarian perspective, however, the analysis does show the fallacy of a claim that repossession necessarily creates net social losses because debtors always lose value. Also, if speculation is fair, repossession may create net social gains. This is because debtors seem more likely to default when they care relatively less about retaining possession; in the langage used here, defant often occurs when the value the debtor attaches to the collateral is not mach above its market price. The smaller is the debtor's loss, the more $1 \mathrm{ikely}$ is it to be outweighe? by the gains repossession creates for the creditor and second bayer. Whether repossession creates net social gains or not, the foregoing analysis also defeats the Kantian fairness objection. Creditors know that repossession often yields them net gains and that second buyers often value resold collateral at in excess of its market price, but the creditors cannot know their debtors' bid and ask prices. Thus creditors never know whether theirs and others gains exceed the debtors' losses; in consequence, creditors cannot be said always to act on the belief that their concerns are of mach greater significance than those of their debtors in respect of the financial costs that attend defaul t.

The second version of the value destruction claim asserts that repossession creates greater harms than gains in consequence of the rapid and extensive depreciation to which consumer goods often are 
subject. This depreciation allegedly is a function of the absence of effective resale markets for used consmer goods. It is said to destroy value because repossessed goods are "worth" more than the undoly low prices they command. 52

Two factors apparently contribute most to the depreciation of consumer goods, neither of which support the conclusion that repossession destroys value. First, new goods command a premium partly because of their newness; consumers, that is, want the experience of the first few drives in a new car or the first views of a new television. Because each such experience can be had only once, when they are important new goods will sell for mach more than used goods. Although the premium that new goods command may sometimes be large because of the "newness" factor, repossession cannot destroy value. The debtor, being the first buyer, by then has consumed the relevant good; he has exhausted the product's newness. Thus he loses nothing when the product is taken and resold at a discount that reflects its used goods character.

A second factor that may contribate to the allegedly excessive depreciation of consumer goods collateral is a function of the greater probability that these goods will fail and of the inability of boyers to observe this probability. To understand the possible effect of the resaltant information asymmetry, suppose that cars are of two kinds, good ones and bad ones, but consumers cannot tell the difference before they porchase. After use, a consumer knows which kind of car he has. An information asymmetry has then developed, since car owners know more than (used) car buyers about vehicle quality. All used cars in similar model classes must trade at the same price, however, for consumers cannot distinguish good from bad. This single price will approrimate the price of bad cars. Were the market price higher than the price of bad cars, all bad car owners would sell their cars and bay good ones. Potential purchasers thus must suppose that far more bad cars will be offered for sale than good ones at any price above the bad car price, and will bid the price down to this low price. A car owner with a good car-and more cars will be good than bad-is therefore locked in. His car is worth more than the (bad car) market price, yet he can only get this price. More to the point, when this debtor's car is repossessed, it will be resold at the bad car price. If the debtor had a good car, and more cars are good than bad, repossession thus inflicts harm on the debtor in excess of the price the car can command in the market. ${ }^{53}$ Moreover, this harm occurs independently of which party is assumed to have a right to the goods in the event of default. If the debtor has the right, he suffers harm in the fashion $j$ ust described. If the creditor has the right, the information asymmetry prevents t. weditor from selling the goods at their "true" value; in consequence, the deficiency that the debtor will have to pay is increased.

Although debtors sometimes may lose value in the sense at issue here when goods are repossessed. for three reasons the conclusion that repossession creates net social harms does not follow. First, the quality of some used goods, such as furniture, seems 
observable before purchase. As to this collateral, the information a symmetry on which the argament rests does not exist. Second, suppose a good repossessed car actually is offered for sale at the bad car price. In consequence, the percentage of good cars in the used car market has increased, al though used car buyers do not know this. A buyer of this repossessed car thus gets a windfa11, a good car at the price of a bad ono. This gain mast be set against the loss that the debtor suffered; depending on the parties' preferences, repossession again could create net social gains or losses. For example, if the debtor used the car occasionally for recreational use but the second buyer was a traveling salesman, the second buyer probably would gain more from owning a good car than the debtor woold lose by being without one. Third, market institutions often will correct for the information asymmetry, so that repossessed items-here cars--will be sold at their "true" worth. One such institution is the gaarantee. An antomobile dealer who resells the cars he repossesses can conveniently learn the quality of these cars, and has an incentive to rese11 the good ones with the appropriate used car guaranty. Thus repossessed cars probably trade at prices that approximate their value. When institutions such as garantees are effective, debtors do not lose value in the sense at issue here. 54

The third way in which repossession is said to destroy value is through the destraction of human capital that repossession creates. To see how this conld occur, suppose the debtor owns a car that always starts if treated in a certain way but will not start in cold weather if treated otherwise. The car is then repossessed and resold bat the second buyer is ignorant of its character. The investment the debtor made in learning how to use the car is thus destroyed, with no offsetting gain. 55

Value is lost when human capital is destroyed in this way, but the losses seem occasional and slight for three reasons. First, human capital will not exist respecting many consumer goods. There is no trick to making a couch work. Second, people seldom need tricks to make new goods work. This is partly because they often do work. When they do not--a new car does not start in cold weather-the goods commonly are fired onder warranty or a disadvantaged buyer has the right to revoke his acceptance. Since repossessed goods of ten are nearly new-defaul can occur only during the payment period-debtors seldom will have invested human capital in learning how to use them. 56 Third, most consumers lack technical skills. In consequence, the methods they develop to make used goods work commonly are easy to discover. The second buyer in the illustration above thas should quickly learn how to start the car. These three reasons taken together show that the destruction of human capital inherent in repossession is too trivial to support extensive restrictions on security interests in consumer goods.

In summary, if the harm that repossession imposes on debtors is conceptualized in "economic" terms-debtors lose human capital or the difference between the goods' value to them and its pricerepossession imposes trivial harms, no harms at a11, or harms that 
cannot be shown to exceed the gains, depending on how one considers the harm to have been inflicted. Onder none of these outcomes are the atilitarian and Kantian objections to repossession persuasive.

If "psychic" rather than "economic" costs are considered, debtors could suffer losses from repossession not of set by gains elsewhere, at least in theory. Suppose that debtors are humiliated when creditors foreclose on 1 iened property. Then if (i) creditors derive no pleasure from repossessing other than the pleasure of redacing the debt; ( $i i)$ buyers of repossessed goods derive no pleasure from knowing (if they do know) that the goods were repossessed and (iii) debtors woold regard the forceable withholding of a portion of their wages from each paycheck-garnishment-as less humiliating than repossession, coercive property execution imposes psychic harms not offset by gains elsewhere. 57

This 1 ine of attack against repossession is unconvincing given present understanding of the phenomenon. Initially, whether repossession creates net psychic losses is uncertain. Assumption (i) above is problematic and assumption (iii) is more so, for while the debtor's family and close friends would know whether garnishment or repossession has occurred, garnishments seem at least as public as repossessions, since garnishments become known to the debtor's employer and coworkers. Further, banning repossession entails costs. Onder current $1 \mathrm{aw}$, creditors have the choice of repossession or garnishment. That many creditors choose the former method suggests that it sometimes has advantages over the 1atter. 58 Banning repossession thus will create costs that must be set against any psychic losses that repossession may cause. Precisely comparing these sets of costs seems impossible so a utilitarian case against repossession is unpersusive even when psychic costs are considered. Finally, in the absence of a coherent claim that repossessions impose greater dignitary harms on persons than garnishments, a Kantian case against repossession, on the ground that it inevitably is disrespectfol to debtors, again is not compelling.

IV. IN TERROREM REPOSSESSIONS

The disapproval of security in consumer conterts rests partly on the belief that creditors do not take it to raise revenue in the usaal sense-through foreclosure and resale; instead, creditors use the threat of foreclosure to coerce payment. 59 The belief that security functions primarily as an in terrorem device is 1 inked to the two justifications discussed above: because creditors are indifferent to the returns that foreclosure brings-the failure to marimize c1aim-and because repossessed goods are worth little-the destruction of value claim--creditors must take security only for its threat value. That creditors commonly so act should now seem less plausible, but the issue here is whether in terrorem repossessions are b1ameworthy, however often done. Part IV argues that some of the concerns that seemingly animate the distaste for in terrorem repossessions are misplaced and others are unpersuasive.

Before reaching the analysis, it is helpfol to define an in 
terrorem repossession. Suppose that creditors repossess only when the gains to them from doing so exceed the costs. Let these gains be direct and indirect: direct gains derive from resale revenues; indirect gains derive from the expected improvement in the creditor's collection experience because each actual repossession makes more believable the creditor's constant threat to impose costs on nonpayers. An in terrorem repossession then occurs when repossession costs exceed the direct gains but are less than the sum of direct and indirect gains. This definition captores the allegedly objectionable feature of in terrorem repossessions that they woold not be made except for their value in establishing credible threats. The definition also rests on the premise that repossessions cannot be objectionable, in the sense at issue here, when their direct gains exceed their direct costs, even though they may prodace indirect gains. This is because the debtor's agreement to give security seemingly implies his consent to the ose of security for its plainly legitimate parpose-to redace the outstanding debt.

In terrorem repossessions may be thought improper for ex ante reasons-it is wrong for creditors to coerce payment by threatening foreclosure-or for ex post reasons--it is wrong for creditors to make examples of debtors who differ in no relevant respects from those whose goods are untouched. Regulating secarity is an inappropriate response to the first set of concerns. The alleged evil of threats to take the collateral at once is that the threats may cause debtors to forego defenses to the underlying claim. These defenses are of two kinds: reasons not to pay that are sufficient under current $1 \mathrm{aw}$, such as a creditor's breach of warranty, and reasons not to pay that "in good conscience" shorld prevail, such as the debtor's illness. The response that is called for by the concern that threats of foreclosure conld cause debtors to forego legal defenses is to require creditors to justify their claims to an impartial third party and to permit debtors to assert defenses before the goods can be repossessed. This is best done by means of a preliminary hearing, such as may be constitutiona11y required when creditors attach property under the athority of state statutes rather than private contracts. ${ }^{60}$ In 1 ight of the very small percentage of debtors who conld raise tenable legal defenses to a claim of foreclosure, prohibiting foreclosure altogether or making it materia11y more difficolt are responses that seem disproportionate to the alleged evil.

Critics of security also are concerned with " moral" defenses to nonpayment. The literature supporting regulation often contains claims that debtors fail to pay largely because of circumstances beyond their control, such as illness or unemployment. ${ }^{61}$ The premise underlying these claims apparently is that it is too harsh to make debtors who have suffered such misfortune choose between payment or repossession. Regalating repossessions is an inappropriate response to this concern because the concern actually goes to the circumstances under which payment should be excused. It is best to focus directly on the excuse issue rather than treat it obliquely by restricting security. To see why, suppose that involuntary unemployment is 
thought to be a proper excusing circumstance. ${ }^{62}$ Current restrictions on the taring of security permit a secured creditor to foreclose if he then eschews a suit on the debt or to sue but forego foreclosure. The secured creditor thus can collect at least some of the debt even though security is regulated. If unemployment should excuse payment, however, the creditor should receive nothing. Suppose instead that unemployment is thought not to excuse defant. Then restrictions on security are unfair, because they often cause creditors to be paid less than in full al though debtors have no legitimate excuse for defauting. It is, in short, unwise to respond to the excuse issue by regulating security, because such regulation seemingly insures only that debtors will have to pay too mach or too 1 ittle.

The second set of objections to in terrorem repossessions focuses on their property of making examples of particular debtors. This concern has two aspects. The first is an expectations objection: the debtor whose goods are taken could not reasonably think it woold be he who would suffer. The second is an equality claim: many debtors fail to pay; no good reason exists to punish this debtor. Neither claim is persuasive. Respecting expectations, the signing of a security agreement is notice to the debtor that the goods may be taken if he fails to pay. Also, creditors have incentives to overstate the frequency with which they foreclose, and probably of ten do so. In these circumstances, each debtor should and likely does know that repossession is a live prospect. Thus claims of unfair surprise will seldom be tenable.
The equality claim is not compelling because good reasons exist to make in terrorem repossessions. They redace costs for debtors as a group. This is because creditors have an incentive to use the least cost method of ensuring payment; if this method is banned, more costly onos will be used, and debtors will bear part of the resultant cost increase. If the threat of repossession is the least cost method and is to be effective, some repossessions must be made. The question then becomes whether the equality goal--all debtors should be foreclosed against or none-should take precedence over the group welfare and desert goals-consumers genera11y benefit from selective foreclosure and this debtor deserves to be foreclosed against because he did not pay. In the criminal 1aw, the equality goa1-all persons who commit crimes should be similarly prosecuted and punished-is subordinated to the group welfare and desert goals; no one has a right to avoid conviction because a similar perpetrator was not prosecuted. This principle becomes controversial in only tro circumstances: when the criminals against whom the state seeks to visit sanctions would suffer drastic and irreversible consequences such as being executed; ${ }^{63}$ or when resource constraints enable the state to proceed against only a subset of suspected criminals and the subset is selected by disfavored criteria such as race. By analogy, then, a defaulting debtor whose goods are taken for deterrence reasons has prima facie no better claim of excuse than the burglar who is fairly cangt. Most burglars are not caght, but this burglar actually committed the crime, and burglary is a bad action that may be 
reduced by conviction; by the same reasoning, the debtor failed to pay, and unjustified nonpayment is a bad action that may be reduced by foreclosure. In addition, relevant differences often may exist between debtors whose goods are taken and those who escape. Creditors have incentives to preserve good will while collecting debts. These incentives should lead them to make in terrorem repossessions only against obvious deadbeats; and creditors claim to proceed, in the conterts in which in terrorem repossessions are said to occur, primarily against persons who do not pay without even the moral excuses discussed above.

\section{MORAL OBJECTIONS TO SECURITY}

The justifications for regulating security discussed above, in particalar the claims that repossession destroys value or is done for in terrorem motives, seem animated by a set of inchoate moral concerns. Allowing creditors to take unrestricted security interests in consumer goods is felt unjustifiably to deprive persons of property, but those who believe this have yet to show how their belief follows from current normative conceptions of the sources of property rights. In consequence of the belief and this failure, critics of security often cast moral objections to it in the more familiar langage of economics. These objections should be evaluated directly. Part V attempts to explicate theories of property rights from which objections to security could tenably be derived; it then argues that these objections cannot support present regulation. 64
Two preliminary matters should be clarified before reaching the analysis. First, the argament assumes: (i) people understand that to give a security interest means to anthorize the creditor to repossess the specified collateral in the event of nonpayment; (ii) consumer credit contracts are set forth in readily understandable langage, and requisite disclosures are made in such fashion as to be easily acted on; (iii) consumer credit markets are competitive. These assumptions are made not because they are true but to focus attention on the question whether security is morally objectionable in relatively ideal circumstances. Faguiation to cure the problems generated by the failure of any of these assumptions to obtain in actual markets has familiar justifications that can be derived from unconscionability doctrines.

Second, recent legislation in this area has been influenced by a belief that consumers in unregalated markets pat their property too mach at risk. This belief is partly responsible for two kinds of regalation: restrictions on the taking of security belong to the class that directly 1 imits risk taking; relared requirements for becoming a bankrupt and expanded bankruptcy exemptions, 65 in contrast, ameliorate the consequences of risk taking. An ideal treatment of any particular aspect of this legislation would consider both types of responses to risk taking because they may be related. For example, decisionmakers could want to relar restrictions on risk taking initially because, through bankruptcy legislation, they have minimized the consequences that risk taking generates. This paper nevertheless 
only discusses an aspect of risk limiting regulation. This is because the subject of risk taking in consumer transactions seems too broad and complex to be treated as a whole, given present levels of understanding; rather, the best chance of understanding it apparenty lies in making detailed analyses of various of its parts.

An analysis of property interest objections to the taking of security mast focus on the relationship that people have to physical things. The principal coercive collection devices used in consumer transactions are garnishment and foreclosure. Restrictions on the taking of security will increase the use of garnishments; if one collection device is 1 imited, creditors will shift to the other. Since it is assumed here that collecting debts is an innocent activity in the absence of a bankruptcy proceeding, the question then becomes whether security poses a greater threat to property rights than garni shment does. It is this question that requires an inquiry into the possible evils of creditors taking things rather than money.

Two related theories of property rights, both of which derive from the effect on personal antonomy of the possession of things, seem germane. The first is a welfare rights theory which holds that each person needs an irreducible minimum of physical things in order to lead a fall and antonomous 1 ife. Such a life cannot be led by one destitute of possessions. If the state were to sanction the taring of everything a person owns, it would therefore be permitting the destraction of his ability to be a fall member of society. To treat persons in this way poses a threat to the community's viability and a1 so is impermissibly disrespectfol to them. In consequence, the state should ensure that people will always retain the requisite minimum of possessions. ${ }^{66}$ The second theory focuses more directly on the relation of people to physical objects, holding that people partly constitute themselves through their possession of tangible things; people, in effect, are at least partly what they own. Mach property that people own obviously is "fungible"-a toaster or a tire iron-but some property is "personal" in the sense that the possessor's personality is bound op with owning it-a wedding ring or a home. The same property may be fungible to one owner and personal to another because people invest themselves in different kinds of things, but the relevant point is that some property is personal in a wholesome rather than a fetishistic sense. If the state were to allow the taking of anything a person may own, it must necessarily allow the taking of "personal property"; this could result in the destruction of important aspects of people's personalities. Because people have a right to be whole, they have a right to own : ise things in which their wholeness partly resides. 67

Both of these theories accnrd people rights to things that are good against (at least some forms of) involuntary divestment. The issue in this contert, however, is e-ienability: can a person voluntarily pledge his refrigerate or his father's watch as security for a $10 a n ?^{68}$ In answering this question, it is helpfal to distinguish between security interests of this sort and purchase money security interests, which are taken by sellers or lenders to secure 
the purchase price. Parchase money security interests are common in connection with installment sales of consumer goods. It would be contradictory of the property rights theories just set out to prohibit them. If people prefer to give parchase money security interests rather than pay higher interest rates or cash prices, making parchase money security less attractive to creditors will compel people to forego parchases or will increase their difficalty in porchasing. Respecting the welfare rights theory, it is contradictory to increase the costs to a person of assembling the irreducible minimum of goods necessary to his leading a full and antonomors 1 ife, in the name of enabling him to lead that life. If a particular item would be included in the set of items that it is thought essential for a person to orn, difficalties should not be put in the way of his acquiring that item. Respecting the second theory, it is contradictory to increase the difficolty a person has in boying goods that will become a part of himself, in the name of protecting $h$ is interest in goods that are a part of himself. Because both relevant property theories protect people's rights to om things, these theories seemingly should permit persons to alienate-to mortgage--goods when alienation will materially increase the opportunity for ownership. Moral objections to the giving of security thas must inhere in the nnrelatedness of security to acquisition; people can give purchase money security interests but perhaps should not be allowed to mortgage what they already own.

The conclusion that broad security interests in consumer goods should be restricted does not follow from the notion of unrelatedness alone. To see why, recall that people now are free to sell their possessions: a person can convert the irreducible minimum of goods to cash or se11 "the old home place." 69 This freedom is only partly justified by administrative convenience; for institutions such as conservatorships exist or conld be fashioned to prevent people from selling all their goods. Rather, the freedom to sell is also justified by notions of personal antonomy. Should these notions permit sales but prevent mortgages?

Answers semingly must derive from the uncertainties that attend the mortgage decision. One such answer may run like this: a person deciding whether to make a present sale of his property can know what affect on his 1 ife being without the goods at issue will have; more accurately, he can know this as well as he can know most things about himself. The decision to mortgage, in contrast, requires a person to predict the effect on his 1 ife of the later forceable removal of many of his possessions or a significant few. The experience of repossession, however, may be incommensurable, in the sense that one must experience it to know it. In consequence, people cannot adequately assess the threat to their antonomy that mortgages pose. To permit an unregulated right to mortgage thus is to cause persons heedlessly to imperil their autonomy by putting their possessions at risk.

This justification for 1 imiting the ability to mortgage rests on a factual premise that is difficult to evaluate. If people have no 
appreciation at all of the consequences of giving security, regulating or prohibiting it is uncontroversial. On the other hand, if people have as full an appreciation of what it means to mortgage as to se11, mortgages should be allowed. No one knows, however, what people actually understand or need to understand about the mortgage decision, in the sense of understanding now at issue. When the oltimate question is factual bot the facts are very hard to get, it is often sensible to resolve the matter by considering the consequences of assigning to one or the other position the borden of persusion. Part $V$ next makes three argaments in support of the view that people should be allowed to mortgage whatever they are allowed to se11, at least until further facts about the mortgage decision are developed. These argaments have a common theme, which is that the restrictions on personal antonomy that seemingly flow from constricting people's ability to transact are unacceptable unless the autonomy enhancing effects of a limited right to transact are plain. Because these latter effects are obscure in this contert, the property rights objections to 1 imiting security that are discussed here should fall.

The first argament is that the uncertainties which attend the decision to mortgage are not unique. Our society allows people to make many decisions that importantly affect their futures, such as where and at what to work, whom to marry, whether to have children, whether to be soldiers and where to 1 ive. People seem equa11y well equipped to evaluate the potentially adverse consequences to them of borrowing on the strength of a used car. Nor do these consequences appear graver than those people face in other areas where autonomy is given scope. Until new facts shatter the common sense intuition that the mortgage decision is relevantly similar to decisions that people can now freely make, people should be allowed to mortgage.

The second argument is concerned more directly with the potentially contradictory effects on antonomy that flow from restrictions on the ability to transact. These restrictions could increase antonomy, in the sense of enabling people to keep a necessary minimum of goods or a particularly important few, but the restrictions also could decrease antonomy by diminishing the set of transactions people can make. It is argued below that limiting the ability to give security decreases the antonomy of poor persons, in this latter sense, more than that of middleclass persons. The autonomy enhancing effect of this regulation, however, is difficult to assess. When the antonomy increasing effect of regulation is anclear but its autonomy decreasing effect seems both clear and especially bardensome to a group commonly thought most in need of help, the regalation is prematrie.

Respecting the effect that limiting security has on poor persons, regalation of the sort described above creates incentives for creditors to 1 end to better risks, raise interest rates or shift to other forms of security, such as second mortgages on homes. ${ }^{70}$ This change in the mix of credit offerings constricts the ability of poor people to borrow more than it constricts the middleclass. This is because poor people are relatively bad credit risks, are less able to 
pay high interest rates and seldom can offer second mortgages. To show that regalation of this sort has a differential effect on the poor's antonomy, however, it is not enough to show that the 1 aw imposes greater constraints on them. If freedom of contract poses a greater threat to the poor's autonomy than to the autonomy of others, correspondingly greater restrictions on the poor's ability to contract are necessary.

Two ways to show that security poses a peculiar threat to the poor exist but neither seems persuasive. The first is to argue that the poor are less able than others to make intelligent choices between risking garnishment or foreclosure; as a result, they will risk foreclosure too frequently. The few studies of the poor's ability to condact commercial transactions fail to support the conclusion that they have less competence than others to make decisions of this sort. ${ }^{71}$ Thus this argument is without persusive factual support. The second way to show that security poses a greater threat to the poor's autonomy is to establish that erroneous economic choices have graver consequences for them. In this contert, such an argument seems straightforward: the poor own fewer goods through which to realize themselves than do the middleclass; hence, foreclosure poses a greater threat to their antonomy. For this argament to succeed, however, a theory must exist relating the nature of a loss to its effect on autonomy. No such theory is now available.

To perceive the effect of this absence, suppose that a middleclass person gives a second mortgage on his home to finance recreational expenditures. The debtor knows that he will have difficulty in paying the debt when it is due, but expects to refinance it on the strength of appreciation in his home's value. Instead, interest rates rise and housing prices fall, in consequence of which the debtor defauls and loses his home. ${ }^{72}$ The debtor has not only lost monoy but also social status, for he no longer is a homeowner; he cannot realize his 1 ife plan in the manner he had expected. Also, he has lost a place with which his "personhood" may have been bound ap. Do losses of this sort pose less grave threats to personal antonomy than a poor person's loss of particular household effects, such as a television? It is difficalt to derive an answer to this question from either of the property theories discussed above. But if the relation between type of loss and atonomy is obscure, the claim that greater restrictions on the poor's ability to contract are necessary because unregalated contract poses a greater threat to the poor's autonomy cannot be sustained. Rather, what is left is the apparent fact that regulation 1 imiting security constrains the choices of poor people more than it constrains the choices of middleclass people, even though no showing has been made that the poor's antonomy is put more at risk by the mortgage decision. To justify a role that makes things relatively worse for poor people, the autonomy enhancing effects of this rale for all should be plain. The illustration above, however, also apparently disproves this; what is to be gained from restricting security, in terms of increases in the ability of persons to lead foller and more free 1 ives, is quite hazy. In consequence, regulating 
the mortgage decision more heavily than other decisions seems premature.

The third argament in support of treating mortgages like sales is that whatever threat to autonomy foreclosure may pose should be dealt with in bankruptcy conterts, if at all. This again is largely because of the obscurity of the relevant property theories. The theory that justifies allowing people to retain an irreducible minimum of goods in order to lead foll and autonomous 1 ives is of little help in specifying the minimum in a concrete sense, partly because the minimum varies as among persons. Also, the theory that protects "personal property" is unable to identify in a general sense what property falls into this class apart from a few paradigm cases, again because what is personal varies with people's preferences.

Restrictions on the taking of security thos will be both over and nnderinclusive; they will leave particular people with too few or too many goods or goods of the wrong kinds. The degree of misspecification cannot nor be assessed given the relatively primitive nature of the theories. To be sure, doing some of the right thing often is preferable to doing nothing, but the issue is when the something should be dono. The choice is to pursue autonomy concerns in the contert of bankruptcies, largely by exempting assets, or to pursue them prophylactically, by prohibiting contracts. It was said above that giving a general answer to this question requires a fuller treatment than can be attempted here. But when so 1 ittle is known about the effects-in the relevant moral sense--of restricting contracting, it seems more appror $i$ isce because less intrusive to pursue the moral concerns discussed here in the bankruptcy contert, when financial disaster has actualy occurred. At least then the 1aw confronts people who plainly need help.

To summarize, moral objections to security apparently follow from a concern for personal antonomy; people should be allowed to retain a minimum of goods, or goods that have peculiar significance to them, in order to lead foll and autonomous 1 ives. The question these objections pose, however, is not whether people should have rights to things against involuntary seizure but whether whatever rights they do have are alienable. Persons should be allowed to give purchase money security interests because this form of security enables them to acquire the things in which their antonomy partiy inheres. The case against security of other sorts must 1 ie in the supposed inability of people to perceive fully the threat to their antonomy that mortgages pose; for society's moral intuitions seem untroubled by the right people now have to sell property that they cannot fully lien. The ability of persons to mortgage, however, should be treated as the ability to sell now is. This is because moral theories that relate antonomy to the possession of things seem insufficiently developed to justify the actual interference with autonomy that restricting the ability to mortgage seemingly creates.

\section{CONCLUSION}

The ability of parties to consumer credit transactions to 
contract for security interests in consumer goods has been

significantly limited in recent years, and further 1 imitations are commonly proposed. Three justifications for this regulation have been influential with decisiomakers: (i) creditors systematicaly fail to marimize the proceeds from the sale of repossessed collateral, thereby increasing the size of the deficiency judgments that debtors mast pay; (ii) repossession of consumer goods "destroys value," in the sense that debtors lose the difference between the valuation they attach to the collateral and its used goods market price, with no corresponding gain being conferred on anyone; (iii) repossession is not done to acquire the proceeds the collateral could bring but for in terrorem purposes, to coerce repayment. The current opposition to personal property security al so seems animated by moral concerns, in particular the belief that an untrammeled right to repossess will unduly erode the personal antonomy of debtors by depriving them of property necessary for the leading of fall and atonomous lives.

This paper has shown that these justifications cannot support limiting the parties' ability to contract for security. Creditors actually do have strong incentives to marimize the value of repossessed goods, and the sparse available evidence indicates that they do so. Repossessions either do not destroy value at a11 or merely transfer it, thereby vitiating objections to it resting on the premises that it is wasteful or evidences disrespect for persons. In terrorem repossessions occur mach less frequently than is commonly supposed; nor are they morally offensive when their porpose and effect are understood. And the property rights case against security, that its use threatens personal attonomy, cannot sustain 1 imitations on the ability of informed and competent debtors to mortgage their property.

The argument made here, however, does not assert that personal property security should be unregulated. When particular consumers are uninformed or incompetent, for example, traditional contract 1 aw reasons drawn from unconscionability theory support refusing to enforce unpleasant aspects of tiri contracts they make. Of greater importance, "markets for contract terms" sometimes may not reach competitive equilibria because of the expense to consumers of acquiring information about their contracts; a good case for regulation often exists when informucion problems cause markets to behave bad1y. 73 Regalation folloring from traditional unconscionability theory or that is likely to cure information problems, however, differs in form and effect from the restrictions on security discussed here. ${ }^{74}$ It is regulation of this latter type that is without coherrent justification and that should not be osed. Attention instead should tarn to the question whether contracts to grant security interests in consumer goods raise problems similar to those thought to be raised by contracts containing broad warranty disclaimers and the 1 ike. 
APPENDIX

The proof belor generalizes the examples in the tert to show that it always pays a creditor to maximize the proceeds of resale. The intuition underlying the proof is that a bird in the hand-the collatera1-is worth more than a bird in the bush-the chance of collecting a deficiency in foll.

D $\quad$ Total unpaid debt

M = value of a maximizing resale

$\mathrm{N} \quad$ = value of a nonmarimizing resale

I = discount rate for bankruptcy recovery ( 8.12 on the do11ar in the text)

p = probability of debtor insolvency

$R_{m}=$ creditor's recovery when he maximizes resale value

$R_{n}=$ creditor's recovery when he does not maximize

resale value

D - M = Debt remaining after a maximizing resale $=$ A.

D - N = Debt remaining after a nonmarimizing resale $=B$.

If $R_{m}>R_{n}$, it pays to maximize.

$R_{\text {m }}=M+(1-p)(A)+p(r)(A)$

$R_{n}=N+(1-p)(B)+p(r)(B)$

Thus it will almays pay to maximize if $M+(1-p)(A)+p(r) A>N$

$+(1-p)(B)+p(r) B$.
Rearranging terms yields $M-N>(1-p)(B-A)+p(r)(B-A)$. Now $M-N=B-A$ becanse the difference between a maximizing and a nonmaximizing resale is the difference between the value of the debt remaining after a nonmaximizing resale and a maximizing resale. Let $\mathbf{M}-\mathbf{N}=\mathbf{X}=\mathbf{B}-\mathbf{A}$.

The inequality then becomes $X>X((1-p)+p(r)(X))$. The left hand side of this inequality always is larger than the right hand side because, $p$ and $r$ being fractions, the right hand side must always be less than $X$. Thus it is always the case that $R_{m}>R_{n}$; creditors always do better by maximizing.

The right hand side of the inequality becomes smaller as $p$ becomes larger. This shows that the expected loss to the creditor from failing to maximize increases with increases in the probability that the debtor will become insolvent. See tert at note 47, snpra. 
FOOTNOTES

* Manrice Jones, Jr. Professor of Law, Dniversity of Southern California Law Center; Professor of Law and Social Science, California Institute of Technology. This paper was originally given as an Addison J. Harris lecture at Indiana Oniversity Law School

(Bloomington). I am grateful for the extraordinary hospitality extended to me by the Indiana Law School, and for the useful comments its faculty made on a prior version of the paper. The paper also benefited from comments received at a seminar in Contract Theory held in the Berkeley Law School and at O.S.C., Law Center Faculty Workshop. In addition, Alan Arelrod, Me1vin A. Eisenberg, Thomas Jackson, Will T. Jones, Michael Moore, Stephen J. Morse, Margaret Jane Radin, John Schmitz, Matthew Spitzer, James Strnad and Louis Wilde also made very helpful suggestions. Portions of this paper will appear in different form in A. Schwartz and R. Scott, Commercial Law: Principles and Policies (1982).

1. J.C.C.C. Section 5.116. The section applies to collateral that "is or may be claimed to be exempt from execution on a money judgment under" state $1 \mathrm{aw}$, but not to purchase money security interests or antomobiles.

2. See tert at notes 20-24, infra.

3. See, e.g., "Consumer Credit In The Onited States." Report of The National Commission On Consumer Finance 27 (1972). A purchase money security interest is taken by a seller or lender to secure the debt the buyer incurs in making the purchase. Oniform Commercial Code Section 9-107.

4. See Schwartz, A Reeramination of Nonsubstantive Unconscionability. 63 Virginia Lar Revier 1053(1977). The caveat respecting social atility follows from the possibility that ontsiders to a contract may prefer that it not be made or made in a different form. In this circumstance, enforcing the contract as made reduces the utility of the outsiders; depending on the relevant magnitudes, enforcement could actually diminish social utility. This possibility seems remote as regards consumer contracts. Also, in consumer conterts the outsiders desiring nonenforcement are likely to occupy social statuses higher than those of the consumer parties. When this is so, nonenforcement increases the atility of the relatively well off at the expense of the relatively worse off, which redistributes wealth in the wrong direction. See id. at $1061-63$.

5. See R. Nozick, "Anarchy, State and Utopia" (197)): J. Mackie, "Ethics: Inventing Right and Wrong" 10-11,116-17(1977).

6. See Eisenberg, The Bargain Principle and Its Limits, 95 Harvard Law Review 741 (1982); Schwartz, supra note 4 .

7. See Williams v. Walker-Thomas Furniture Co., 198 A.2d 914(D.C. App. 1964). This paper uses the term "contract 1 aw reasons" to 
capture the notion that some legal problems are best analyzed from an ex ante or contract 1 aw perspective, where the primary concern is whether a set of outcomes--e.g. contracts-was generated by a normatively satisfactory process, rather than analyzed from an ex post perspective, where the primary concern is whether a set of outcomes is itself satisfactory, decided largely independently of the process that generated it. In a more concrete sense, the term contract 1 aw reasons refers to reasons that would be grounds for refusing to enforce according to such standard contract 1 aw doctrines as unconscionability. The reasons about to be considered as justifications for the regulation described above fit uneasily, if at all, into standard contract doctrines, which may explain why consumer goods security problems seldom are analyzed in contract 1 aw terms. D1timately, of course, there are only good or bad reasons for regulation.

8. A third possible set of reasons that could justify restricting security has to do with the nature of security generally. Secured debt may sometimes have undesirable distributional consequences or be a less efficient form of credit than unsecured debt. This third set of reasons now seems not well enough understood to justify regulation. See Schwartz, Security Interests and Bankruptcy Priorities; A Review of Carrent Theories, 10 Journal of Legal Studies 1(1981).

9. U.C.C. Sections 9-504; 9-507.
10. These three themes are discussed in an interesting and comprehensive paper, Whitford, A Critique of the Consumer Credit Collection System, 1979 Wisconsin Lar Revier 1047 .

11. "Consumer Credit in the United States," supra note 3, at 31 . Of the four justifications for regulation 1 isted above, the first, that creditors systematically fail to marimize the proceeds of repossessed collatera1, seemingly could be analyzed onder the contract $1 \mathrm{aw}$ doctrine of good faith; failure to maximize, that is, could constitute a violation of the creditor's daty to act in good faith. However, while a violation of the duty of good faith would be grounds for a defense to an action for a deficiency, standard contract theory does not provide that the possibility of violations of the daty can support a prophylactic ban on an entire class of transactions. The second justification apparentiy has no contract analogue. Nor does the third, because the creditor's exercising a contract right in order to collect a debt that is legally owing apparently does not constitute economic doress. The fourth justification also falls without contract $1 \mathrm{aw}$ because contract $1 \mathrm{aw}$ is not concerned with the assignment of property rights but rather with the trades that right holders are free to make.

12. It is annecessary to this paper's argument to decide whether consumers are adequitely informed respecting the prices and terms that constitate credit contracts. See tert at notes 6-8, supra. 
For a discussion of hor the state should make such determinations and respond to the existence of inadequate information see Schwartz and Wilde, Intervening in Markets on the Basis of Imperfect Information: A Legal and Economic Analrsis, $127 \mathrm{~J}$ Pa. L. Rey, 630 (1979); Schwartz and Wilde, Competitive Equilibria in Markets for Heterogeneous Goods Onder Imperfect Information: A Theoretica1 Analysis with Policy Imp1ications, 12 Bell J. Econ. 181 (1982).

13. See Magnuson-Moss Act, 15 D.S.C. sections 2301-2312(1976).

14. Mach of the argament made below al so applies to state statutes that permit creditors to execute on property after a judgment of default is rendered. Indeed, execution laws may be thought of as state supplied security terms. This paper focuses on consensual security interests because much regulatory attention has been devoted to them; readers can make the obvious connections to execution 1aws. Those laws, however, regulate repossession sales differently than does the Code and thos deserve independent stady.

15. UCC section 9-507 (1).

16. E.g., Wilmington Trust Co. v. Conner, 28 U.C.C. Rep 900(De1.1980).

17. E. g., Mack Financial Corp. v. Scott, 606 P.2d 993 (Idaho 1980).
18. E.g., Mercantile Financial Corp. v. Miller, 292 F. Supp. 797(E.D.Pa.(1968); Credit Burear Metro, Inc. v. Mims, 119 Cal. Rptr. 622(Super.Ct.1975).

19. DCCC Section 3.301 .

20. DCCC Section 5.103 .

21. UCCC Section 5.116 .

22. West's Ann. Calif. Civil Code Section 1812.5

23. Rev. Code Wash. Ann. Section 62(A) Section 9-501(1).

24. New Merico Stats Section 50-15-7(J)(1973). Alabama, Arizona, Colorado, Idaho, Indiana, Kansas, Oaklahoma and Utah ban deficiencies in sales finance cases when the price of goods is less than a specified amount, usaally 81,000 . [citations]. Massachusetts, Maine, Oregon, West Virginia and Wisconsin have similar statutes, most of which apply also to secured loans. [citations].

25. Proposed Trade Regulation Rale "Credit Practices," 16 C.F.R. $444.2(a)(4)$.

26. Id. at $444.2(\mathrm{a})(7)$.

27. These justifications also support related regalation. As an example, Sections 5.110 and 5.111 of the DCCC accord consumers a right to cure defaults: if a consumer is in defaut for ten days 
for failure to make a payment, the creditor is required to send a notice of defant; the consumer then has twenty days to care the default. The creditor cannot foreclose during the requisite thirty day period. Comment 3 to 5.110 explains that the right to core is meant to prevent excessively prompt repossessions. This seemingly suggests that creditors do better by repossessing, selling the goods for less than their face value and suing for a deficiency. The first and most well known claim for this view is Shochman, Profit on Defan1t: An Archiva1 Study of Antomobile Repossession and Resale, 22 Stanford Lar Revier 20(1969). The right to cure also is justified, in the comment, as preserving the consumer's ability to present defenses before repossession, Which is a major theme underlying the distaste for in terrorem repossessions. See tert at notes 59-60, infra.

28. "Credit Practices" Staff Report and Recommendation on Proposed Trade Regalation Rale 16 CFR Part 444, Federal Trade Commission Burean of Consumer Protection 288 (footnotes omitted) (integers added) (1980).

29. Id. at 289 .

30. The 8.12 figare is a very rough approximation. A well known early study reported that creditors recover approzimately 8.08 on the dollar in insolvency proceedings. See V. Conntryman and A.

Kaufman, Commercial Law 170(1971). More recent stadies show that in 1977 creditors received no money at all in 81 percent of bankruptcy cases. In cases in which assets were distributed, general creditors received 27 percent of the 8229 million available for distribution--\$61 :i111ion--but more than $\$ 1.1$ billion of claims were discharged. A creditor suing for a deficiency is a general creditor, and is unlikely to do as well as 8.12 on the dollar if the debtor does go bankrupt. See V. Countryman, A. Kaufman, 2. Wiseman, Commercial Law Cases and Materials 250(1982). On the other hand, some deficiencies may be collected without bankruptcies. iecovery percentages reported by major creditors to the F.T.C. ranged from 6 percent to 25 percent of dificiencies outstanding but the figures were ambiguous in some cases. See White, Consnmer Repossessions and Deficiencies: Ner Perspectives from Ner Data, Boston University Lar Revier (forthcoming 1982). The text's conclusions, as the appendix 1ater shows, are not sensitive to the precise portion of the debt that creditors can recover in deficiency actions. See tert at pp. $62-63$.

31. See tert at pp. $66-67$, infra.

32. The tert supposes marginal cost to be constant per dollar collected; its conclusion is unlikely to change if collection costs increase with increases in the dollars creditors seek-in economic parlance, if the second derivative of the marginal cost curve is positive. To see how marginal cost conld increase in this way, consider first a creditor's resale efforts. The 
creditor might find it relatively easy to sell a repossessed car for 80 percent of its "value," bat have to put in considerable effort to convince a consmer to pay the fall 100 percent. The marginal cost carve for collecting deficiencies al so could increase with increases in the dollars sought, for two reasons. First, suits for larger amounts are more likely to be seriously contested than suits for smaller amounts, and courts may also require stronger showings when the consequences to consumers of losing become grave. Second, the cost of collecting judgments might increase with the size of the judgments; collecting the first 60 percent, that is, may be simple but collecting the rest difficult becanse debtors will be less cooperative, more likely to hide assets and so forth. The tert's assmption of constant marginal cost for both collection methods--resale and suit-is consistent with the standard observation that marginal cost is constant over wide ranges of output. This note's analysis saggests that, in foreclosure contexts, the tert's assmption is less likely to hold. But it also shows that if marginal cost does increase with increases in the amounts of dollars creditors seek, the cost increases will attend both collection methods. The tert's assumption of constant marginal cost thas seems unlikely to bias the analysis, al though it would be helpful to have more information on creditor costs than now exists.

33. Creditors may be thought to have an incentive not to maximize resale proceeds in order to impose a penalty on defanting debtors; the penalty would be the difference between the collateral's fair rarket value and the lower resale price the creditor actually obtains. This penalty would be imposed to deter defauls. See Part IV, infra, discussing in terrorem repossessions. For such a penalty to be effective, debtors woold have to know both that creditors will fail to marimize, and the consequences to debtors of this failore. If debtors were this informed about possible creditur post-default strategies when they initially bought credit, however, they could canse creditors to face the choice of abandoning unfair strategies or losing business. This paper plausibly assmes a lower level of debtor bowledge. See tert at note 12 , supre. A consequence of this assumption is to render ineffective a creditor strategy of not maximizing in order to penalize and thereby deter defaults. Also, creditors should be reluctant to make explicit the intention not maximize, for this woold be to admit openly to an illegal practice.

34. For claims in this regard, see e..g.. "Credit Practices," supra note 25, at 275-87,317-18; Comment, Defanlting Debtors and the Judicial Process-The FTC's Imposed Restriction on Deficiency Indgments: section 444.2(c)(7) of the Rnle on Credit Practices, 8 Connecticnt Lax Review 457(1976); Note, I Can Get It For Yon Wholesale: The Lingering Problem of Automobile Deficiency Judgments, 27 Stanford Lar Review 1081(1979). 
35. See text at note 26 , supra. White, supra note 30 , proposes that the retail price should be presumptive evidence of the maximizing price; creditors conld rebat the presumption "by establishing suitable facts concerning the condition of the repossessed vehicle or unique market circumstances." Two states have adopted 1 imited versions of the rale requiring firms to credit consumers with the retail price. Florida Statates Annotated Section 516.31(3) (applies only to 1 icensed sma11 loan companies); Connecticat, C.G.S.A. section 42-98(g) (retail value is an important element in determining the "fair market value" that firms mast credit against deficiencies).

36. The FTC, proceeding by adjudication, recently held that an antomobile dealer committed an unfair trade practice by charging indirect expenses sach as overhead and lost profits to consumers who had defanted and whose cars were repossessed. It was industry practice to make such charges. On appea1, the Ninth Circuit reversed without reaching the merits, holding that the rale developed by the FTC "will have general application" because "credit practices similar to those of the dealer are widespread in the car dealership industry," and therefore the FTC had to proceed by rolemaking; it could not create such a widespread rale through adjudication. Ford Motor Co. V. FTC, 654 F.2d 599,601(9th Cir. 1981). The justification for allowing retailing banks or dealers to recover profit and overhead is identical to the justification for allowing sellers to recover these items under section 2-708(2) of the UCC. Creditors invest resources in creating facilities to retail used goods; if they cannot recover the resultant capital and fired costs (profit and overhead), they will not be pat in the position they would have been had debtors performed.

37. Many creditors testified before the FTC that they made wholesale sales because they preferred to 1 end rather than sell cars. See "Credit Practices," supra note 28, at 289-90. The FTC staff said of this policy that it "reflects the fact that higher retorns are available to the creditor when resources are devoted to activities other than U.C.C. sales," bat the staff believed that this application of the principie of comparative advantage injured consumers. Id. at 290-91. The tert next shows that this belief is false.

38. In a recourse financing arrangement, the dealer extends purchase money credit to the consumer and sells the consumer's obligation to a financer. If the consumer defaults, the dealer is responsible for collecting the debt; thas the dealer commonly repossesses and resells the collateral.

39. Section 9-504(3) of the UCC requires a creditor to give the debtor notice of a repossession suie, and section 9-506 gives the debtor a right to redeem the collateral by paying the debt in foll plus the creditor's expenses. If a creditor proposes to sell the collateral for mach less than its value, the debtor, in 
theory, could refinance on the strength of its actual value and redeem. Thus both versions of the cartel explanation mast presuppose the inefficacy of debtor redemption rights. Consistent with this presupposition, defanting debtors seldom redeem; the causes of this failure seem unclear.

A third way in which creditors could do better by not maximizing woold be for them to buy at their own repossession sales. Using the figares in the example above, suppose that the creditor repossessed a car worth $\$ 3,000$ when the debt was $\$ 5,000$, "sold" the car to himself for 81,500 , and sued for a 83,500 deficiency; the creditor later sold the car to another for 83,000. The creditor woold do better than if he initial1y had sold the car for $\$ 3,000$ because while in both cases he recovers the car's actual value, in the latter case he could claim only a $\$ 2,000$ deficiency. Creditors sometimes do boy at their own repossession sales, but the evidence fails to show that they claim deficiencies greater than those claimed by creditors who do not. Perhaps this is because courts will scrutinize more carefully sales to oneself and because a debtor could so easily show bad faith in these cases; a comparison of the sale to oneself with the sale to others woold generally suffice. In this connection, section 9-507 of the DCC, which creates a statutory penalty for noncompliance with Article 9, seems less toothless than is commonly supposed. As an example, in one case the amount financed on a car was $85,938.67$ and the finance charge was
81,363.51. On default, the creditor resold the car without giving the debtor the statatory notice and sued for a deficiency of $81,392.61$. The debtor, representing himse1f, successfully claimed that the failure to give notice invoked the 9-507 penalty; that this penalty amounted to $81,957.37$; and that the deficiency claim thus was wiped out. See Garza v. Brazos County Federal Credit Union, 608 S.W.2d 298 (Tex.Civ. App. 1980).

40. See, e.g., "Consumer Credit in the United States," supra note 3 , at 31 .

41. A good analysis of the factors seemingly conducive to collusion is found in F. Sherer, "Industrial Market Structure and Economic Performance" 199-227(1980). See a 1so Koh1man, Natare and Significance of Price Fixing Rings, 2 Antitrust Lar and Economics Review 69(1969). The analysis above ignores two factors commonly discussed in connection with cartels, the effect on the likelihood of cartel behavior of the ability of fims to innovate and of declines in demand for the industry's product. See Sherer, supra, Kuhlman, supi:; almer, Some Economic Conditions Conducive to Collusion, 6 Journal of Economic Stadies 29(1972). These factors are ignored here because potential cartel members are retail dealers and thas have a 1 imited ability to innovate, and because the proponents of thi failure to maximize justification apparently asser: its applicability under all market conditions. The factors the tert does discuss mast be 
regarded as tentatively valid because they are based primarily on stadies of cartels that have been prosecuted. Whether these factors characterize all firms or only those in the "prosecution prone" category is unknown, but the factors are the best we have. See Asch and Seneca, Characteristics of Collnsive Firms, 23 Journal of Industrial Economy $223(1975)$.

42. See authorities cited in note 41 , supra.

43. See Sherer, supra note 41 , at 306-12.

44. The FTC staff asserted that collusive practices were common but that their "clandestine nature" made it "impossible to quantify their prevalence." A California bank did testify to the Commission that it faced "undoly depressed bidding" when making "remote dispositions" of collateral. It avoided the problem by creating a "centralized 'Co1lateral Control Center." See "Credit Practices," sapra note 28, at 292. Apparent1y, no other financial creditor testified respecting collosive bidding. In very small towns, few enough dealers may exist to make plausible their attempting to form a cartel, but as the testifying bank's experience shows, the regional nature of used car markets makes the success of such cartels onlikely.

45. The FTC study indicated that Ford Motor Credit Company obtained 82 percent of the wholesale book value, Bank of America obtained 79 percent of wholesale and Security Pacific National Bank recovered 77.1 percent of wholesale. See "Credit Practices," supra note 28 , at $266-67, n_{.42}$. The Stanford study showed that creditors in Alameda County, California, received 84 percent of the wholesale book valuo. See Note, supra note 34, at 1085. A stady of repossessions in Washington, D.C., indicated that creditors obtained 81 percent of the wholesale value. See Note, Business as Usua1: An Empirical Study of Antomobile Deficiency Judgment Suits in the District of Columbia, 13 Connecticnt Lay Rerier 511,516-21(1971). Professor Schuchman's initial stady of Hartford, Connecticut repossessions revealed a 71 percent average and a 75 percent median recovery of wholesale valuo. See Schuchman, supra note 27 , at $62-67$.

46. General Motors Acceptance Corporation reported to the FTC that its repossessed cars were in "good," "fair," "poor," or "wrecked" condition. GMAC c1aimed to recover 94.4 percent of wholesale value on good cars and 80.8 percent of wholesale for fair cars. ("Credit Practices," supra note 28 at 300.) A recent study using FTC data reached approximately the same results. See Schuchman, Condition and Yalue of Repossessed Antomobiles. 21 William and Mary Lar Revier 15 (1979).

47. Firms with different cost structures sometimes do agree on a cartel price. Widely varying cost structures make agreement difficult, however, because firms have an incentive to misrepresent their costs, and otserving individaal fim 
production functions is expensive for outsiders to do. Potential members of dealer trading cartels have incentives to misrepresent their costs and their bad debt experience, both of which are costly for outsiders to observe.

48. One study reported that deficiencies were no 1 arger than usual When financers resold to dealers pursuant to recourse arrangements and the dealers then sued the debtors. See Comment, Defan1ting Debtors and the Judicial Process, supra note 34. Another study showed that deficiencies were lower in this circumstance. See Schuchman, supra note 25 , at 40 .

49. The difficulties discussed above respecting dealer trading cartels seemingly could be avoided by secret side payments. For example, if the dealer in the first illustration in Part IA sold the $\$ 3,000$ car for $\$ 1,500$ and sued for a $\$ 3,500$ deficiency, bat later received a secret 8500 side payment from the second dealer, he would do $\$ 236$ better than if he sold the car for $\$ 3,000$. No cartel would be necessary; rather the market would have repossessing dealers offering cars for less than their actual value to whoever would make the highest side payments. In the limit, the side payment would equal the difference between the maximizing and nonmaximizing price $(\$ 1,500$ in the text's example). But if this is so, the side payments woold actually run the other way; the first dealer would sell the car for 83,000 , its actual price, less the sum the second dealer would demand to cooperate in creating a bill of sale that said "81,500." Apparent1y no one believes that such b1atant 1ying about the prices at which collateral is resold is common. This may be because lying would be relatively easy to detect if the repossessing creditor reported the difference between the $\$ 3,000$ actually received and the $\$ 1,500$ claimed to be received in the deficiency action to its shareholders and on its tax retarns. On the other hand, the failure to report this income is grounds for criminal sanctions.

50. W and $V$ are likely to differ because of income effects. A consumer's demand for goods is partly a function of his wealth. If the right to keep particular goods on default is a "normal good," a debtor would spend the same proportion of his income on this right regardless of how mach he makes. Because a debtor without the right is poorer-by the value of the right-than a debtor with the right, a debtor without it would spend less of his income in dollars to purchase it than he would charge in dollars to give it op. Pat simply, a debtor is richer if he owns the right and thas will value the right more, if the right is a normal good. The tert assumes the right to keep the collateral on default to be a normal good, and so supposes $W$, the ask price, to be greater than $V$, the bid price. Income effects are commonly used to explain differences in bid and ask prices. If the right to keep the goods were an "inferior good," a consumer would spend a larger proportion of his income on it if he were poorer. In 
this circumstance, V actually could exceed W.

51. Another form of the value destraction claim that is sometimes made is that consumers lose the goods' replacement value while creditors recover only the used goods market price. If replacement value is conceived of as this used goods' market price, this form of the claim adds nothing to what has been said; the consumer can replace his used goods with other used goods, paying $P$, and so loses V - P. If replacement value is conceived of as the new goods price, this version of the claim is false. Consumers default when the value to them of retaining the goods is less than the unpaid price (D $>V$ ). Since the ner goods price mast exceed D, consumers would not bay new goods and so woold not lose the new goods replacement value.

52. This claim is commonly made. See "Credit Practices," supra note 28 , at 227,321 and anthorities cited in note 189, id. See also Whitford, supra note 10 .

53. This argument is drawn from Aker1of, The Market for "Lemons": Qualitative Uncertainty and the Market Mechanism, 84 Quarterly Journal of Economics, $488(1970)$. For a recent treatment of the theory, see Wilson, The Nature of Eonilibrium in Markets with Adverse Selection, 11 Bell Jonrnal of Economics 108 (1980).

54. The problem could also be less serious than is commonly supposed if debtors were more likely to default when they own bad cars.
Commentators sometimes attritat. the value loss debtors may suffer to the absence of well aeveloped markets for used goods (see anthorities cited note 52, snpra) but the alleged absence of such markets is not explained. A market for private goods conld fail to arise for supply side reasons, such as barriers to entry, or demand side reasons, such as consumers' onwillingness to pay enough to have the product be prounced. Supply side obstacles to the formation of used goods markets seem slight, for entry into retail markets is relatively cheap. The tert discusses two demand side obstacles, that consumers want only to parchase "newness" and that information asymmetries may make consumers reluctant to purchase. Neither obstacle seems serious enough to support the value destraction claim. Also, casual observation seems inconsistent with the commentators' belief. At 1 east in cities, consumer darables can commonly be purchased used, which suggests the existence of viable used goods markets.

55. Professor Leff first made this claim. See Leff, Injury. Ignorance and Spite: The Dymamics of Coexcive Colloction, 80 Yale Lay Journal 1 (1970).

56. This observation is more true of purchase money security than of security interests that lenders take in their debtors' existing possessions, for some of these possesssions will not be new.

57. For an argument along these 1 ines, see Wallace, The Logic of Consumer Credit Reform, 82 Ya1e Lar Journal 461(1973). 
58. Income execution-i.e. garnishment--has higher procedural costs than private repossession because courts are involved. Also, income execution can be more costly than repossession because large claims may take longer to recover. This delay imposes two sorts of costs: (i) If creditors earn more with money than the legal rate of interest, delay creates opportunity cost losses; (ii) Delay also increases the 1 ikel ihood that debtors will go bankrupt and thas erase part (or a11) of the debt. In addition, although it is unlawfol for an employer to dismiss an employee whose wages have been garnished only once, employers are commonly believed often to dismiss or othernise sanction garnished employees. This is a cost pecoliar to income execution.

59. A typical statement of this view asserts that nonpurchase money security interests "equip a creditor with a capacity to threaten the consumer with extreme deprivation to induce the consumer to acquiesce to the creditor's demands whether or not the demands are reasonable." "Credit Practices," sppra note 28, at 193-94. See al so id at 210-11; J. Spanogle and R. Rohner, "Consumer Law Cases and Material s" 328(1979); Whitford, supra note 10.

60. The constitutional requirements are described in Mitchell v. W. T. Grant Co., 416 J.S. 600(1974). A hearing is not constitutionally required when the creditor repossesses porsuant to a Code security interest. E.g., Adams v. Southern California First National Bank, 492 F.2d 324(9th Cir.1973), cert. denied 419
J.S. 1006(1974). See al so Flagg Bros., Inc. v. Brooks, 436 J.S. 199(1978). The Model Consumer Credit Act (1973), drafted by the National Consumer Law Center, requires repossession to be by action, section 7.202, but no state has adopted this statute. Wisconsin has come close, requiring repossession to be by action unless "the customer has surrendered the collateral. "Wisconsin Consumer Act Section 425.206(1)(b)(1973). A surrender "is not . - voluntary" if it is "made parsuant to" the creditor's "request or demand" or "pursuant to a threat, statement or notice by the ... [creditor] that [it]... intends to take possession of the collateral." Id. at Section 425.204(3). The text does not advocate hearings prior to repossession but only argues that if reasons exist to make tenable a belief that threats to repossess often cause consumers to forego legal defenses, the appropriate remedy is a hearing, not the regalation of security. A major debate took place in the 1970 s over whether a hearing should be constitutionally required when creditors attached goods pursuant to state statute. Opponents of the requirement argaed that debtors seldom had good defenses and that hearings would be excessively costly; proponents disputed both assertions and claimed that consumers had a dignatary interest that unregalated attachment could violate. A representative exchange is Johnson, Denial of Self-help Repossessions: An Economic Analysis, 47 Sonthern California Lar Revier, 82(1973); Daner and Gilhool, The Economics of Constitutionalized 
Repossession: A Critione for Professor Johnson, and a Partial

Reply, id. at 116; Johnson, A Response to Daner and Gilhoo1: A Defense of Self-help Repossession, id. at 151 . See al so Scott, Constitutional Regulation of Provisional Creditor Remedies: The Cost of Procedural Dre Process, 61 Virginia Lar Revier $807(1975)$.

61. See, e.g., "Credit Practices," sapra note 28, at 236.

62. That unanticipated financial hardship should excuse defaul is considered in Wallace, The Uses of Usury: Lor Rate Ceilings Examined, 56. BUL Rev. 451, 468-70 (1976).

63. See Radin, Crue1 Panishment and Respect for Persons: Super Dae Process for Death, 53 Southern California Lar Revier 1143 (1980).

64. The literatore supporting the reforms discussed here seldom explicitly justifies them on distributional grounds, but a distribational theme may underlie the case for regulation. If so, for two related reasons the theme is inappropriate. The supply of consumer credit probably is elastic in relation to the demand; that is, credit suppliers apparent1y can sell money in nonconsumer markets more conveniently than consumers, especially 10w income consumers, can forego debt. This being so, mach of the cost of regalation $w i 11$ be passed on to debtors, in the form of higher prices, reduced credit availability or less favored purchase terms. The two reasons why this outcome is unsatisfactory are: First, because mach of the cost is passed on, the resultant redistribution is less from creditors to debtors than among the debtors themselves. The defaulters gain at the expense of those who pay higher interest rates or are denied credit. To the extent that default is within the control of debtors--persons can borrow wisely or otherwise manage their affairs appropriately--requiring "innocent" consumers to subsidize defaulters seems difficalt to justify. Second, credit markets are believed to segment; the middle class and rich commonly bry and borrow from different firms than the poor do. Thus wealth is anikely to $r:$ : edistributed across class 1 ines, but rather within social classes. See Whitford, supra note 10. Poor consumers who pay higher interest rates or are denied credit subsidize poor consumers who defant. This outcome seemingly tares the wrong group.

65. See Bankruptcy Reform Act of I978, 11 U.S.C. Section 522(f); Section $1325(a)(5)$.

66. Legal analyses of welfare rights theories are found in Grey, Property and Need: The Welfare State and Theories of Distribational Jnstice, 28 Stanf Lar Review 877(1976); Michaelman, Helfare Rights in a Constitutional Democracy, 1979 Washington Lay Quarter1y 659.

67. This second theory is set out in Radin, Property and Personhood, 34 Stanford Lar Revier __(1982). It has Hegelian roots. 
68. Modern property theory recognizes three sources of property rights, broadly speaking. One source derives from the Lockean notion that a person owns things in virtue of his miring his 1 abor with them; a second derives from atilitarianism, holding that rights should be assigned in such fashion as to maximize atility; and the third derives, in a more or less immediate sense, from concern for individnal personality, assigning rights to people in such ways as to preserve or create their ability to be fully free. This paper speaks only of the third source of property rights because the relevant legal issue is when people can alienate things. Lockean theory seemingly assumes a virtually untramelled right of alienation; once one has acquired rights in a thing, by miring one's labor with it, nothing internal to the theory supports restricting the person's power to exchange that thing for another. Otilitarianism al so supports a broad power to alienate, especially if the modern view that people can best choose the actions that maximize their own utility is accepted. For then, voluntary exchanges must be permitted, on the ground that they are made only when they marimize the atility of the parties to them. In contrast to Lockean and atilitarian theories, an unrestrained power to al ienate conld erode the basis of the property right itself when that right derives from notions of individaal personality. This is because, as we will see, persons could alienate property necessary to their leading antonomous 1 ives or necessary to their personhood. The support that personality theories of property may give to restraints on alienation may partly explain why objections to freedom of contract in consumer conterts sometimes have a welfare rights tone. The tert thas attempts to show that even personality theories cannot sustain present regalation of consumer goods security.

69. See Hutchins $v$. Honeycutt, 286 N.C. 314,210 S.E.2d 254(1974).

70. The FTC staff said of its proposed role banning security interests in household goods that it was "not [meant] to prevent consumers from borrowing on the equity in their homes, stocks and bonds." Credit Practices, supra note 28, at 244.

71. See Schwartz, suprą note 4 , at 1079-81.

72. For stories 1 ike this, see "Croative Ringncing" Comes Homes to Roost in Bankraptcy Court Los Ange1es Times Part IV 1-2, December 28,1981 .

73. See Schwartz and Wilde, Intervening in Markets on the Basis of Imperfect Information: A Legal and Economic Analysis, 127 University of Pennsylyania Lan Revier 630(1979).

74. These differences shoold not bs overstated. For example, the most appropriate response to information problems is to require disclosure, bat if the costs of disclosure are excessive an outright ban of a particular practice is occasionaly the best 
solution. These cases, horever, are unlikely to correspond closely to the cases for regalation that have been developed from the four justifications rejected here, because information problems raise quite different issues.

The statutes criticized here may also be thought of as provisions of a state supplied insurance contract; debtors pay higher interest rates but are "insured" against an unpleasant consequence that would otherwise attend defaut, the consequence that is repossession. The question then is whether the insurance contract is optimal. This largely is a function of whether creditors are informed, an issuo beyond the scope of this paper. In addition, if those statutes are regarded as an insorance policy other quostions arise. For example, do the statutes genorate an unacceptable level of moral hazard, in the sense that they help canse an excessive nmber of defaults? If these statutes were repealed, and if creditors had difficulty distinguishing debtors 1 ikely to defart from those who are not, would 10 risk debtors have an incentive to grant excessively broad security interests to creditors as a way of demonstrating their creditworthiness? See Schwartz, supra note 8 , at 14-21; Rea, Arm-Breaking Conspmer Crodit and Personal Bankrupter, Working Paper No. WSIV-10, Law and Economics Workshop Series, University of Toronto (1982). These questions al so fall within the set of contract 1 aw reasons excluded from discussion here, bot which are of considerable importance. 